\title{
The effects of postindustrial employment configurations on father-child involvement in urban fragile families
}

\author{
Michael G. Cina \\ West Virginia University
}

Follow this and additional works at: https://researchrepository.wvu.edu/etd

\section{Recommended Citation}

Cina, Michael G., "The effects of postindustrial employment configurations on father-child involvement in urban fragile families" (2005). Graduate Theses, Dissertations, and Problem Reports. 4142.

https://researchrepository.wvu.edu/etd/4142

This Thesis is protected by copyright and/or related rights. It has been brought to you by the The Research Repository @ WVU with permission from the rights-holder(s). You are free to use this Thesis in any way that is permitted by the copyright and related rights legislation that applies to your use. For other uses you must obtain permission from the rights-holder(s) directly, unless additional rights are indicated by a Creative Commons license in the record and/ or on the work itself. This Thesis has been accepted for inclusion in WVU Graduate Theses, Dissertations, and Problem Reports collection by an authorized administrator of The Research Repository @ WVU. For more information, please contact researchrepository@mail.wvu.edu. 


\title{
THE EFFECTS OF POSTINDUSTRIAL EMPLOYMENT CONFIGURATIONS ON FATHER-CHILD INVOLVEMENT IN URBAN FRAGILE FAMILIES
}

\author{
Michael G. Cina
}

A Thesis submitted to the Eberly College of Arts and Sciences at West Virginia University in partial fulfillment of the requirements

for the degree of

\author{
Master of Arts \\ in \\ Sociology
}

Rachael A. Woldoff, Ph.D., Chair

S. Melissa Latimer, Ph.D.

L. Christopher Plein, Ph.D.

Division of Sociology and Anthropology

School of Applied Social Sciences

\section{Morgantown, West Virginia}

2005

Keywords: Fatherhood, Underground Economy, Fragile Families

Copyright (C) 2005 Michael G. Cina 


\title{
ABSTRACT \\ THE EFFECTS OF POSTINDUSTRIAL EMPLOYMENT CONFIGURATIONS ON FATHER-CHILD INVOLVEMENT IN URBAN FRAGILE FAMILIES
}

\begin{abstract}
Michael G. Cina
Research shows that many inner city fathers work a variety of jobs to make a living for themselves and their families. While some fathers work in traditional jobs that are regulated and taxed, others generate income "off-the-books" or through illegal work called "hustles." This thesis uses data from the Fragile Families and Child Wellbeing Study to assess the impact of hours worked in regular jobs, off-the-books ventures, and illicit hustles on fathers' involvement with their eighteen-month old child. The regression results show that fathers who spend increasing hours hustling tend to be less involved with their children than fathers who work regular jobs and/or work off-thebooks. These effects persist even after controlling for fathers' age, race/ethnicity, educational attainment, cohabitation, and relationship with their child's mother.
\end{abstract}


To all parents who struggle to make ends meet in our inner cities. 


\section{ACKNOWLEDGMENTS}

I am grateful to Rachael Woldoff, my advisor, who helped me to refine my research skills, knowledge of statistical inference, and writing style. I am grateful for her empathy and persistence.

Melissa Latimer introduced me to the principles of research design and countless other concepts in the discipline that are scattered throughout this work. I am also thankful to Chris Plein, who provided invaluable and insightful criticism from a social policy perspective. I sincerely appreciate the time and effort these professors spent as active committee members.

I grateful to the Bendheim-Thomas Center for Research on Child Well Being at Princeton University for permission to use the Fragile Families and Child Wellbeing Study. I appreciate the generosity of the National Institute of Child Health and Development and the consortium of private foundations that funded the Fragile Families and Child Wellbeing Study. 


\section{VITA}

May 18, 1980

May 2005 (anticipated)

August 2003 to present

April 2005

2004 to 2005

August 2005

(Anticipated)

April 2005

May 2003

April 2003

Fall 2002 - Spring 2003

April 2003

\section{FIELDS OF STUDY}

Major Field: Sociology
Born - Youngstown, Ohio

M.A. Sociology, West Virginia University, Morgantown, West Virginia

Graduate Teaching Assistant, Sociology and Anthropology, West Virginia University

Awarded Outstanding Graduate Teaching Assistant in Sociology, Eberly College of Arts \& Sciences, West Virginia University

Dean's Graduate Advisory Board, Eberly College of Arts \& Sciences, West Virginia University

Professional Presentation, American Sociological

Association

Professional Presentation, North Central Sociological Association

B.A. Sociology, West Virginia University, Morgantown, West Virginia

Awarded Outstanding Senior in Sociology, Eberly College of Arts \& Sciences, West Virginia University

Dean's Undergraduate Advisory Board, Eberly College of Arts \& Sciences, West Virginia University

Professional Presentation, North Central Sociological Association 


\section{TABLE OF CONTENTS}

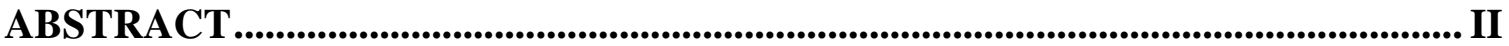

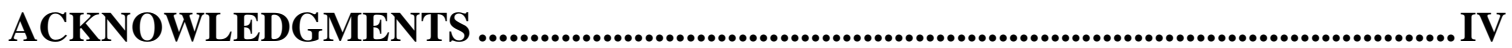

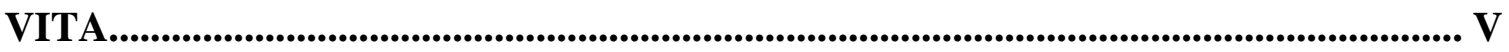

THE RESEARCH PROBLEM............................................................................................... 1

RESEARCH HYPOTHESES ......................................................................................... 3

CONCEPTUAL FRAMEWORK............................................................................. 7

PATERNAL INVOLVEMENT: CONCEPTUALIZING FATHER WORK....................................... 7

MAKING A LIVING IN THE URBAN LABOR MARKET …………....................................... 8

RACE, ETHNICITY, AND FATHER INVOLVEMENT ……........................................... 11

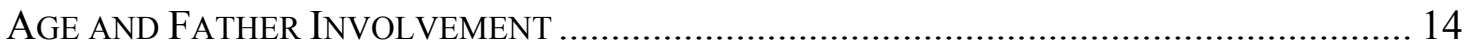

EDUCATIONAL ATTAINMENT AND FATHER INVOLVEMENT .......................................... 14

COHABITATION, MOTHER-FATHER RELATIONS AND FATHER INVOLVEMENT ................. 16

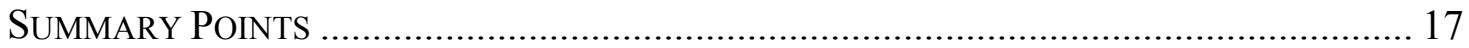

DATA, MEASURES, AND METHODS.................................................................. 19

INSTRUMENTATION AND DEPENDENT VARIABLE OPERATIONALIZATION........................ 21

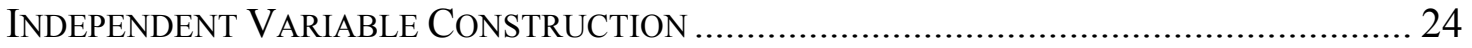

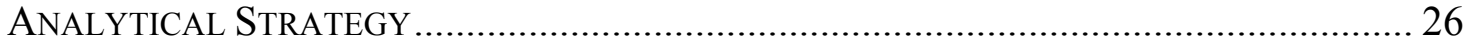

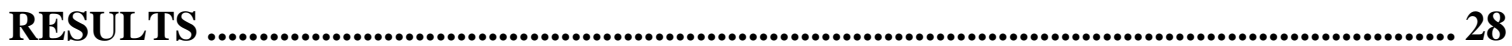

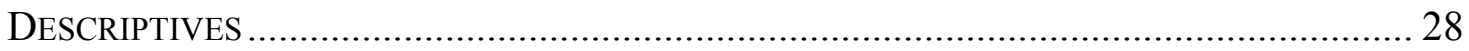

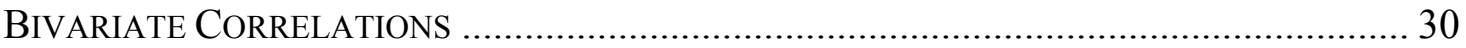

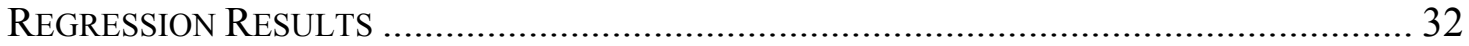

DISCUSSION AND CONCLUSION ........................................................................... 38

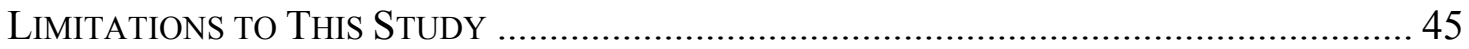

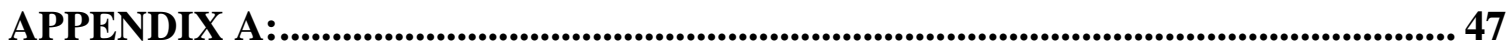

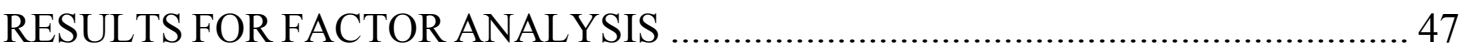

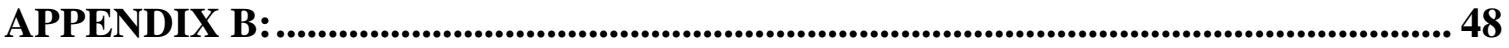

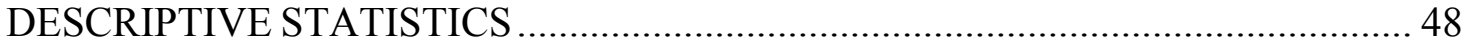

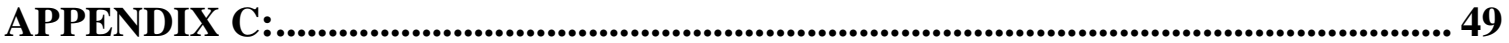

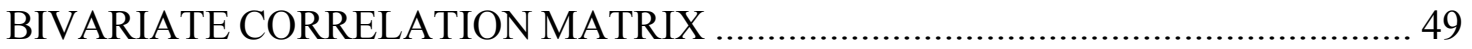

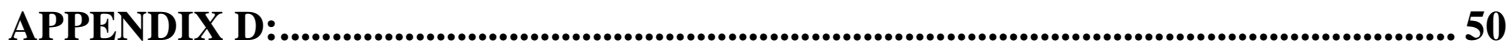

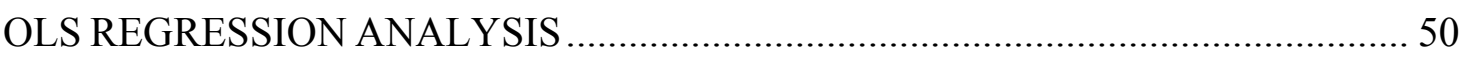

WORKS CITED................................................................................................................. 51 


\section{CHAPTER 1}

\section{THE RESEARCH PROBLEM}

Thirty years of declining two-parent households and rising birth rates in inner cities have left American children in fragile families with compromised levels of father presence. Many researchers blame these phenomena on three decades of deindustrialization, stressing the correlation between diminishing employment opportunities for low skill, inner city men and the drastic decline in traditional motherfather families (Anderson 1998; Kasarda 1989; Levy 1980; Wilson 1987, 1996; Wilson and Neckerman 1986). These researchers have documented an economically bifurcating labor market (Wilson 1987, 1996), declining wages (Jencks 1992; Pattillo-McCoy 1999), joblessness (DeParle 2004; Koch 1999; Wilson 1987, 1996), and a growing dependence on the underground economy (Sullivan 1989; Wilson 1996; Venkatesh 2000).

American social policy also changed during the economic upheaval of deindustrialization. Whereas public policy makers fought a war on poverty throughout the 1960 s and early 1970 s, their objectives changed by the 1980 s into a war on welfare (Katz 1990). For example, evidence shows that Aid to Families with Dependent Children (AFDC) and General Assistance (GA) benefits fell by about 33\% in constant dollars between 1970 and 1985 (Katz 1990). Additionally, the Reagan administration eliminated benefits to 200,000 Supplemental Social Security recipients (Katz 1990). In 1996, the Clinton administration's Personal Responsibility and Work Opportunity Reconciliation 
Act (PRWORA) ended welfare in its original form, which provided federal dollars to mothers whose husbands had deserted or divorced them, or who simply never married (Katz 1990). Unlike AFDC, PRWORA shifted financial accountability from the federal government to welfare-receiving families, emphasizing labor force attachment, term limits, and work requirements to receive aid, even in places where the economy was severely depressed. Furthermore, PRWORA required mothers to establish paternity for nonresidential childbirths and required fathers to pay child support without granting explicit rights to visitation (Reichman et al. 2002). Some research shows that the intention of PRWORA to strengthen low income families by increasing their autonomy actually undermined the vulnerable lives of mothers and fathers in both urban (Danziger et al. 2001; McLanahan and Sandefur 1994; O'Campo and Rojas-Smith 1998) and rural areas (Kohler et al. 2004; Latimer 2004).

The obvious lesson of deindustrialization and 1990s welfare reform is that work is an integral part of the father-child relationship. Nevertheless, few quantitative studies actually examine labor market practices and the father-child relationship. Instead, the existing research explains the limited opportunities for and within marriage (Testa et al. 1989; Wilson 1987), issues related to child support (Stier and Tienda 1993), and problems associated with changes to the family structure, such as the spread of single parent families (Furstenberg 1995; Furstenberg and Cherlin 1991; Jencks 1992) as well as groups' use of multigenerational households as a strategy to avoid poverty (PattilloMcCoy 1999). Literature on gender and family also tends to omit studies about work and the father child relationship; instead emphasizing the changing paternal role in families 
(Burton and Snyder 1998; Lamb 1998), how men's lives are affected by marriage (Nock 1998), and the gendered ways that men contribute to their children's lives (Amato 1998). As researchers investigate these issues, underemployed inner city men often go to extremes to generate income in the age of welfare reform (Edin et al. 1998). The fathers in Edin and colleagues' study (1998) report earning income in the regular service sector, off-the-books, and through risky, illicit hustles, like drug sales. My research answers five questions that have not been addressed by prior social science research. First, are fathers whose employment is limited to illicit hustles (i.e., selling drugs, pushing stolen goods) less involved with their children than all others and, if so, is this effect independent of other factors? Second, what other underground or legitimate work configurations affect father involvement, and how? Third, what effect do demographic factors like age and race play? Fourth, what effect does education have on father involvement? Finally, net of other factors, how do mother-father relations affect father involvement?

\section{Research Hypotheses}

I make three hypotheses that build on research related to fatherhood, inner city employment, and crime. First, I hypothesize that the amount of time spent in regular work positively affects father-child involvement. Research shows that employment encourages high levels of paternal involvement for a variety of reasons (Chase-Lansdale 2000; Johnson 2000; Marsiglio 1991). First, fathers who work a regular job may do so as part of their perceived duty to be a good provider and "show love and affection" (Edin et al. 2000; Kalil 2003). Second, their ability to provide financially for their families tends to leave them in good standing with their children's mothers; in turn, good mother-father relations often have a profoundly positive effect on father-child relations (Edin et al. 
2000). Finally, fathers who select into regular work, particularly in the face of more lucrative underground work or hustles, are likely to have what Anderson (1999) calls "decent" values. In other words, they value personal accountability for their actions, curtail deviant behaviors, and are responsible. They may be more religious and often work very hard (Anderson 1999). Ultimately, these fathers' willingness to work a regular job and invest financially in their child reflects their level of involvement (Johnson 2000).

In my second hypothesis, I expect that time spent working off-the-books in the quasi-legitimate underground economy positively affects levels of father-child involvement. Note that I distinguish "legitimate" off-the-books work from hustles. In his study of a Chicago public housing project, Venkatesh (2000) draws a similar line that is based on inner city residents' perceptions of work as legitimate or detrimental to their own lives. Project residents determined the legitimacy of work by how much certain kinds of work made them feel threatened. For example, Venkatesh (2000) wrote that project residents did not feel threatened when hairstylists solicited business an elementary school parking lot, when unlicensed taxi cabs waited outside stores, and day laborers advertised outside hardware stores for off-the-books work. However, drug dealers and prostitutes compromised public space (Venkatesh 2000). Hustles like these could cause entire households to be evicted from the projects, or negotiate residents' safety by bringing strangers into buildings or causing verbal altercations that have the potential to escalate into destructive violence (Venkatesh 2000). He found that underground work is more than an instinctive coping mechanism for poverty; it was a "cultural practice through which people developed a sense of who they are" relative to others in the housing project and in larger society (Venkatesh 2000). 
I maintain that quasi-legitimate, off-the-books work is likely to positively affect father-child relations for two reasons. First, the literature suggests that economic deprivation is linked to father absence, poor mother-father relations (Danziger and Radin 1990; McLanahan 2001), and fathers' inability to take long-term responsibility for children (Sullivan 1993). Fathers earning money off-the-books generate some revenue, and do so in a manner that is probably consistent with what their child's mothers and society would deem as legitimate and less harmful. Second, fathers who work off-thebooks tend to understand the need to be good providers to their children (Edin et al. 2000). It is likely that they care about their children to the point that they must "innovate" new ways to assure wellbeing (see Merton 1938), since the regular sector cannot financially sustain their fathering endeavors (Rich 1999). Just as they invest financially in their child, they are likely to invest emotionally, while avoiding the realm of major deviance and risky behavior.

Taken from urban vernacular, movies, and music (Venkatesh 2000), "hustle" became a sociological concept referring to illicit activities that generate income, including activities such as narcotic and gun trafficking, gambling rackets, prostitution, and bribing government officials. I hypothesize that the number of hours spent hustling negatively impact the father-child relationship. While fathers who hustle may care strongly about their children and sell drugs or push stolen goods, for example, to support their infant (Edin et al. 2000), these activities also hamper fatherhood across three dimensions: risky behavior, mother's disapproval, and role incompatibility. First, unlike regular and off-the-books work, illegal work of this nature disproportionately exposes fathers to situations that are negatively correlated with fatherhood, such as violence, 
problematic drug and alcohol use, criminal activity, and incarceration (Edin et al. 1998; Waller and Bailey 2002). Second, mothers may quickly end or threaten to end relationships with fathers who are involved in risky behavior (Waller and Bailey 2002) or illicit hustles (Edin et al. 2000). Third, hustles are incongruent with the nurturing role required of fatherhood, and men who are serious about taking care of their children are more likely to exit hustling roles (Edin et al. 2000). Since fathers who work in the illicit underground economy have diverged far enough from the norms of "decent" economic behavior (Anderson 1999), they are more likely to select into "street" behaviors associated with this role, compared to fathers who do "legitimate" off-the-books work. 


\section{CHAPTER 2}

\section{CONCEPTUAL FRAMEWORK}

This research examines how hours spent in various types of employment affect father-child involvement among low-income, urban fragile families. Recent research on fatherhood consistently points to important demographic, educational, and relationship factors and I considered these in doing this project. I review each of these predictors of father involvement in the context of the bifurcating urban labor market.

\section{Paternal Involvement: Conceptualizing Father Work}

Past literature divides paternal involvement into two different categories, "fatherhood" and "fatherwork." Fatherhood research addresses the "structural arrangements" and "cultural expectations" associated with being a father, such as marriage, divorce, cohabitation, and paternity. In contrast, "fatherwork" looks at the on going physical and emotional efforts that men assume when they become a parent (National Center on Fathers and Families 1999). In contrast, "fatherwork" incorporates three dimensions: "responsibility," “availability,” and “engagement” (Lamb 1987). "Responsibility" includes the work that fathers complete to ensure their children are cared for and safe. Similarly, "availability," refers to the accessibility of the father to the child. Finally, engagement refers to the activities taking place between father and child during caregiving and socialization; it represents "the persistent efforts that men undertake with and for their children" (NCOFF 1999). Researchers across disciplines, 
such as education, family studies, psychology, sociology, and social policy, use engagement to understand father-child interactions and since it reflects a key dimension of fatherhood (Brown et al. 2001; Cabrera et al. 2004; Tamis-LeMonda 2004). Since I am interested in fathering behaviors exclusively, and because concepts like "accessibility" and "responsibility" are very different dimensions that should not be confounded for theoretical and statistical reasons, I examined only father involvement by measuring engagement practices.

\section{Making a Living in the Urban Labor Market}

Economic factors are important determinants of father involvement (Coley and Chase-Lansdale 2000; Danziger and Radin 1990; Johnson 2000). The literature examining employment and fatherhood indicates that the changing economy hampered father involvement across three macro and micro dimensions: declining two-parent families in new poverty areas, impeding fathers' abilities to be "good providers," and enabling fathers' abandonment of their families, which is a way they cope with the shame of not being able to provide.

In the first dimension, ecological research associates the bleak economic circumstances for fathers with a decline in father involvement. Many researchers maintain that two-parent households declined as deindustrialization progressed, resulting in increases in female-headed households (Anderson 1998; Jencks 1992; Wilson 1987, 1996; Wilson and Neckerman 1986). The literature amply documents that deindustrialization has limited the employment opportunities of inner city men, and this has been harmful to the family structure in the inner city (Anderson 1998; DeParle 2004; Jencks 1992; Kasarda 1989; Koch 1999; Levy 1980; Pattillo-McCoy 1999; Sullivan 
1989; Wilson 1996). Research shows that two-parent households declined more considerably during deindustrialization than at any other time in history (Wilson and Neckerman 1986). Other research provides reasons why. In one study, quantitative evidence indicated that persistent economic deprivation in some inner city neighborhoods associated with the diminishing number of traditional two-parent families (Wilson 1996). Many women reported that they felt men were hopeless as fathers (Wilson 1996). These women often feared that men would become involved with them mainly to obtain sex or money, leaving their children and them behind after the fact (Wilson 1996). Other qualitative research reports similar conclusions. Anderson (1998) found that neighborhoods with a lack of family-sustaining jobs limited men's opportunities to form economically self-reliant families. African American men with "street" ideals formed peer groups as a coping mechanism for unemployment and alienation, and these groups tended to emphasize sexual prowess as a way to assert masculinity (Anderson 1998).

Similarly, Sullivan (1989) found that the high rates of female-headed and welfarereceiving households in the African American and Latino communities he studied correlated with the overall lack of opportunity for men to work jobs that pay familysupport wages. Moreover, the elimination of well-paying, entry-level jobs threatened the nuclear family norm prevalent in the predominantly white neighborhood he studied. Even though the norms of this neighborhood dictated that marriage must quickly follow accidental pregnancy, many men who were unable to find jobs abdicated these cultural expectations by turning to drugs, which hampered the opportunity for marriage.

The absence of upwardly mobile jobs brought about by deindustrialization forces men to compete for scarce resources amongst one another (Furstenberg 1995). 
Moreover, this lack of lucrative regular sector jobs has prevented many young fathers from taking long-term responsibility for their children (Furstenberg 1995; Sullivan 1993). The many blighted, low-income urban communities where fathers are absent and lowincome mothers experience strain in trying to parent and work demonstrates Furstenberg's (1995) notion that weak economic circumstances not only bring about father absence, they also enable poor parenting.

The literature presents explanations about how inner city fathers' economic vulnerability impedes their levels of involvement. Numerous studies show that young fathers want to take long-term responsibility for their children, but their lack of educational and economic opportunities hampers their abilities (Anderson 1998; Edin et al. 2000; Edin and Nelson 2001; Furstenberg 1995; Liebow 1967; McLanahan 2001; Sullivan 1993). They try to parent in families under severe financial constrain. These families are more prone to arguments than families under better economic circumstances (Edin et al. 2000), and disagreement over money is one of the strongest predictors of dissolved mother-father relations as children age (Edin et al. 2000). Given that some that so many fathers report that their ability to be a good provider is an essential part of fathering (Edin et al. 2000; Liebow 1967), those that cannot provide financially reported feeling a sense of shame (Edin et al. 2000; Liebow 1967). The persistent fighting, sense of shame, and stigma these fathers feel (Norland 2001; Sullivan 1993), partly explain why so many fathers abandon their families when they cannot provide (Edin and Nelson 2001; Liebow 1967; Stier and Tienda 1993; Sullivan 1989; Wilson 1996). Moreover, financial provisions often influence a mother's decision to allow involvement (Edin et al. 
1998), and many mothers are often reluctant to permit visitation by unemployed fathers and those doing illegal work (Edin et al. 2000).

Research shows that some fathers who could not financially support their children through legal means worked in the underground economy to generate needed revenue (Norland 2001; Rich 1999, 2003; Rich and Kim 2001; Sullivan 1993). Edin and Nelson (2001) reported that many low-income fathers were not jobless; they worked laboriously in jobs that are not recorded in official employment statistics. They asserted that "work for unskilled inner-city fathers has not disappeared, it has simply gone underground" (Edin and Nelson 2001).

The growth of the underground economy in the inner city affects more than just hard-to-employ fathers. The emerging opportunities for illegal sector employment are pervasive even among middle-income people living in the inner city. Pattillo-McCoy (2000) reports that the highly lucrative, ever-present underground economy is difficult for people of all income levels to refuse when faced with uncertain legitimate opportunities for economic success. Before taking the step underground, however, many inner city fathers judge the compatibility of underground work with their role as fathers (Edin and Nelson 2001). These fathers also tended to switch from illegal hustles to off-the-books occupations, which were less dangerous for them and their families (Edin and Nelson 2001).

\section{Race, Ethnicity, and Father Involvement}

Conceptions of paternal obligation, engagement activities, and gender ideologies vary by race and ethnicity. Research shows that there are differences in how race/ethnic groups conceive of paternal obligation. One quantitative study reports that both African 
Americans' and Latinos' view of paternity are in contrast to those of whites; whereas fathers of color view providing direct care as the most important fathering duty, whites perceive financial support as the fundamental paternal obligation (Kalil 2003). Qualitative research shows that African Americans tend to emphasize "being there" or presence was essential to paternity (Allen and Doherty 1996).

Fathers' of different race/ethnic groups also engaged in different childhood activities. Compared to whites, African American and Latino fathers were more likely to emphasize teaching autonomy in early childhood activities, such as "walking, weaning, and toilet skills," possibly due to these fathers' financial and time constraints indirectly resulting from race-related disadvantage (Batrz and Levine 1978). One study reported that fathers' of color endured disproportionate levels of economic hardship, constraining their time and abilities to meet normative paternal responsibilities (Allen and Connor 1997; Madhubuti 1990). Simply put, African American fathers wished they could spend more time with their families providing for their child's needs (Hyde and Texidor 1988, 1994), but were often unable to do so. However, researchers argue that fathers of all race/ethnic groups had to cope with time constraints as an obstacle to paternal involvement, and that other variables were probably involved (Toth and Xu 1999).

The literature contained several inconsistencies when reporting race/ethnic groups levels of engagement and gender ideologies. Some studies reported that even though African American, Latino, and white fathers spent comparable amount of time in primary activities and monitoring their children, African Americans tended to show higher levels of involvement than whites (McLoyd et al. 2000). Another study found that African American fathers were more likely to participate in the daily life of their family, and were 
more likely to be intimately involved in raising their children than Asian, Latino, or white fathers (Rubin 1994). Rubin 1994 also found that nearly three-quarters of the African American fathers in the sample did a substantial amount or majority of the childcare, compared to fathers of other race/ethnic groups. Nevertheless, there is ample evidence indicating that African Americans fathers (Anderson 1999; Ransford and Miller 1983; Toth and Xu 1999) and Latino fathers (Bartz and Levine 1978) were likely to hold less egalitarian and more traditional beliefs about fatherhood. Another study added to these inconsistencies by recognizing that African American fathers tended to be "warm," "supportive," and "emotionally expressive" with their children (Price-Bonham and Skeen 1979; McAdoo 1981) regardless of their socioeconomic status (Allen 1981; Bowman 1993).

This contradictory evidence suggests that race/ethnicity is a complicated predictor of father involvement and other variables mediate its influence. For example, researchers have highlighted that geographic proximity, cohabitation, marriage, and educational attainment mediate the racial/ethnic disparities in father involvement. King and colleagues (2004) found that race or ethnicity alone did not stand out as significant predictors of father involvement. Instead, each racial or ethnic group was mediated by other variables, which together significantly affected involvement (King et al. 2004). One study showed that geographic proximity of father to child in the case of nonresidential fatherhood explained why African American fathers tended to visit more often than white and Latino fathers (Lerman 1993). Another study showed that Mexican American men were likely to marry in response to a premarital conception than African American and Puerto Rican fathers (Testa et al. 1989), which increased their level of 
involvement. Ultimately, different paternal role conceptualizations, economic circumstance, gender perspectives, and mother-father relations suggests that other variables will mediate the effect of race and ethnicity on father involvement.

\section{Age and Father Involvement}

Several studies showed that a father's age impacted their levels of paternal involvement. For example, Danziger and Radin (1990) reported that fathers' age negatively correlated with mother-father relations, help with the baby, discussion about the baby, and overall fathering. This is consistent with recent research. For example, one study found that fathers who were older than 30 were less likely to visit the child's mother in the hospital than those under 20 (Johnson 2000). Nevertheless, other research suggested that adolescents were emotionally immature and thus less involved (Anderson 1989; Sullivan 1993). These studies found that while many adolescents in the inner city were physically mature, they lacked trustworthy role models and a clear sense of the long-term consequences of impulsiveness and risky sexual behavior (Anderson 1989). Indeed, the lack of father involvement and union formation was attributable to emotional immaturity (Sullivan 1993). Similar to race/ethnicity, these inconsistent reports suggest that the effect of fathers' age on involvement will be mediated by other variables in this thesis.

\section{Educational Attainment and Father Involvement}

Educational attainment is a predictor of father involvement across many studies. On the one hand, more educated fathers were more likely than less educated fathers to be highly involved with their children. They tend to show an interest in their child's 
education (Flouri and Buchanan 2003) and for those that enjoyed their careers, they were more likely to have positive interactions with their kids than those who dislike their jobs (Grossman et al. 1988). For instance, one study showed that well-educated men with better occupations and incomes provided better care to their nine-month-olds than those of a lower socioeconomic status (Volling and Belsky 1991).

Despite these reported gains for high socioeconomic status fathers, a considerable portion of the literature contradicted these findings. For example, one study found that unemployed, disabled, or retired fathers were more likely to be involved with their young children than their employed counterparts (Flouri and Buchanan 2003). Several other studies concluded that more involved fathers tended to have less prestigious occupations (Levy-Schiff and Israelashvili 1988; Volling and Belsky 1988). After all, these fathers worked fewer hours (Coverman 1985; Feldman et al. 1983; Grossman et al. 1988; McHale and Huston 1984; Nock and Kingston 1988) and spent considerably less time absorbed in their careers (Heath 1978).

Finally, educational attainment is an important predictor of father involvement because it mediates other variables. For example, at least two studies I found showed that fathers' levels of educational attainment mediated the differences in paternal involvement that were caused by race and ethnicity (Cazenave \& Leon 1987; King et al. 2004). In the first study, all of the racial and ethnic differences in father involvement were mediated by educational attainment, and the mediator effects were more pronounced among whites than fathers of color (Cazenave \& Leon 1987). A similar study also reported this conclusion: white fathers with differing levels of educational attainment exhibited more variability in involvement than fathers of color, who also had 
differing levels of education (King et al. 2004). Accordingly, whites with lowest levels of father involvement in this study had completed less than a high school education, but the highest levels of paternal involvement among whites were for those fathers who had the highest levels of education. These studies show that educational attainment is likely to be an important predictor of paternal involvement in the current study.

\section{Cohabitation, Mother-Father Relations and Father Involvement}

A growing body of research also stressed that cohabitation and good motherfather relations strengthened father presence in a child's life. Parental relationship status was useful in predicting paternal involvement because cohabiting couples were usually romantically involved, while nonresident parents often had nonromantic or uninvolved relationships (Johnson 2000). Furthermore, Johnson (2000) found that mothers in cohabiting relationships were more likely than mothers who were not cohabiting to report that (1) their partners visited the hospital and (2) provided financial support during pregnancy. In fact, cohabiting fathers tended to place a disproportionate emphasis on the breadwinner role (Kalil 2003). Kalil (2003) reported that while most fathers nominate "showing love and affection" as the most important paternal obligation, cohabiting fathers and non-resident fathers in romantic relationships reported greater emphasis on financial provisions to the family. Cohabiting couples also tended to have stronger father presence in the child's life because the family became a joint endeavor and tended to have a higher income. These parents could pool resources to take care of their families (Kenney 2004). The ability to join resources and combine incomes resulted in a $29 \%$ reduction in the proportion of children living in poverty in cohabiting-couple families (Manning and Lichter 1996). Despite these advantages, the literature clearly showed that 
cohabiting fathers differed from married fathers. For instance, they were far less likely to be employed than married fathers (Manning and Lichter 1996), which may be why cohabiting fathers were less involved than married fathers but are still more involved than nonresidential fathers.

There are noneconomic variables that motivate father involvement in the context of the mother-father relationship, even for nonresidential fathers. In the case of divorce, paternal involvement with children varied with the conditions of the child birth and current living arrangements (Seltzer 1991). Fathers with children born within a marriage were usually more involved across the board - paying support, visiting, and decisionmaking - than fathers whose children were born outside of marriage. Paying child support, visiting, and participating in childrearing were complementary activities; fathers who engaged in any one of these were likely to engage in the other two (Seltzer 1991). Ultimately, mother-father relations and cohabitation were important predictors of paternal involvement because of the economic and noneconomic circumstances that accompany them.

\section{Summary Points}

Recent fatherhood scholarship investigated the effects of several variables on patterns of father-child involvement. These independent variables clustered around several substantive areas, including employment status, race and ethnicity, age, educational attainment, cohabitation status, and mother-father relations. Literature pertaining to the labor market revealed two themes concerning this research: (1) familysustaining labor market opportunities for low-skilled inner city fathers were more scarce today than 40 years ago (Jencks 1992; Sullivan 1989; Wilson 1987, 1996); and (2) the 
decision of inner city fathers to assume fathering roles was tied to their abilities to provide for their families (Edin et al. 2000; Stier and Tienda 1993). Similar to the qualitative research by Edin et al. (2001), this thesis quantitatively examines how the new labor market configurations for men in the inner city affect father-child involvement. 


\section{CHAPTER 3}

\section{DATA, MEASURES, AND METHODS}

This cross-sectional quantitative study utilizes data from the Fragile Families and Child Wellbeing Study (FFCW), a nationally representative study of mothers and fathers whose child was born outside of marriage in 1998, and reside in large U.S. cities. The FFCW evaluates the circumstances of unmarried parents and their children over the first few years following non-marital birth. Parents complete an interview at the child's birth and then one year, three years, and five years subsequently. The one-year follow-up data are the primary data I am using; this sample comprises fathers whose children are between 12 and 18 months at the time of the survey. I chose to use the Fragile Families and Child Wellbeing Study instead of other databases because it contains a unique and rich list of questions addressing both fatherhood and illegal work. These data allow me to generalize from a sample of roughly 3,000 inner city fathers to the entire population of fathers responsible for a 1998 non-marital birth in U.S. cities with a population of 200,000 or more. Since this is a representative sample, I can make inferences about employment configurations and paternal involvement one year after the birth of these fathers' child (Babbie 1990).

\section{Sampling Procedure}

The Fragile Families Study uses a stratified random sample of the 77 U.S. cities with a population of 200,000 or more. Analysts stratified the cities into nine types of

environments according to the generosity of welfare benefits, the degree of child support 
enforcement, and the strength of the local labor market. Data managers scored cities to identify those with extreme values for each of several policy and labor market conditions. Then, data analysts randomly selected one city from each of the eight types of extreme environments. These selected cities included two cities with generous welfare benefits, two with strict child support enforcement, two with a strong labor market, and two with a weak labor market. Data managers also selected eight additional cities with moderate policy or labor market conditions. These 16 cities represent the national sample: Austin, Baltimore, Boston, Chicago, Corpus Christi, Indianapolis, Jacksonville, Nashville, New York, Norfolk, Philadelphia, Pittsburgh, Richmond, San Antonio, San Jose, and Toledo (Reichman et al. 2001).

In five cities, researchers were able to interview in all birthing hospitals within the city. Researchers rank-ordered the birthing hospitals from those that had the most nonmarital births to those that had the least in the 13 remaining cities. In a given city, researchers chose hospitals in order, starting with the hospital reporting the largest number of nonmarital births until 75 percent of the non-marital births in the city were covered. In two cities, due to their size, researchers used a simple random sample to select hospitals for the study (Reichman et al. 2001).

Before fielding the survey, researchers obtained approval to interview new parents from each sampled hospital. Data managers recruited a hospital sponsor (usually a clinician) to serve as the local Principal Investigator, and to assist in obtaining human subjects approval from the hospital's Institutional Review Board (IRB). With the sponsor's assistance, researchers submitted a formal request to the IRB to conduct the study. This typically required submission of the survey protocol, participant consent 
forms, survey instruments, and certificates of human subjects training from each Principal Investigator. Once data managers obtained institutional approval from each hospital, field staff who were trained by the data collection subcontractor began to sample mothers.

Data analysts designed the Fragile Families study to oversample unmarried births, while selecting a smaller sample of married births for comparison. At baseline, researchers interviewed 4,898 mothers and fathers. For the one-year follow-up, researchers attempted to reinterview all mothers and all fathers (even those fathers who were initially missed at baseline). According to the FFCW one-year code book, the completed interview sample size for the one-year follow-up data is 3,367 fathers $(69 \%$ of the baseline fathers). Of this sample, 3,124 (93\%) fathers were interviewed both at baseline and one-year follow-up and $243(7 \%)$ were interviewed at the one-year followup only.

The Fragile Families baseline and one-year follow up are composed of interviews with 4,444 families in 16 U.S. cities, selected through stratified random sampling. This database is a nationally representative sample of non-marital births in United States cities of 200,000 or more in 1998. See Reichman et al. (2001) for complete information about sampling design and methods for the FFCW.

\section{Instrumentation and Dependent Variable Operationalization}

I constructed the dependent variable, father involvement, using theoretical and statistical means. First, I gathered codebook items using recommendations in the Fathering Indicators Framework, a theoretical instrument produced by the National 
Center on Fathers and Families (NCOFF) at the University of Pennsylvania. I selected several father involvement variables from the FFCW one-year follow-up codebook using a widely documented set of criteria suggested in the Fathering Indicators Framework (see Barnet and Baruch 1987; Federal Interagency Forum 1998; Lamb 1987). Each variable that I selected indicates the number of days per week a father engages in specific caregiving and socializing activities with his child. While the Fathering Indicators Framework lists three dimensions of fathering, my intention is to measure involvement through engagement practices, rather than through "availability" or "responsibility." I I use engagement because I am interested in fathering behaviors between father and child exclusively, rather than if the father is present or being responsible. In fact, many researchers use engagement practices to understand paternal involvement, since these practices reflect the key dimension of fatherhood (Brown et al. 2001; NICHD Early Child Care Research Network 2000; Tamis-LeMonda et al. 2004). Furthermore, fathers' actions are more interesting than feelings for this study, in part because there is often a disparity between what fathers believe and what they actually do (Liebow 1967).

I assessed the suitability of these theoretical variables by factor analyzing all of the involvement items in SPSS. Prior to performing the factor analysis, I insured the fitness of the data in three ways. First, I examined the correlation matrix and found several coefficients of . 3 and higher. I also found that the Kaiser-Meyer-Oklin value of .881 , exceeded the recommended value of .6 (Kaiser 1970, 1974), and that the Bartlett's Test of Sphericity (Bartlett 1954) was statistically significant $(\mathrm{p}<.001)$, each suggesting the factorability of the correlation matrix. 
I present the results of the principal components analysis in Appendix D. Table 1 of Appendix D reveals two components with eigenvalues exceeding 1, each explaining $53 \%$ and $13 \%$ of the variance, respectively. The eigenvalue of a factor represents the amount of the total variance explained by that factor (Pallant 2001). Using Kaiser's criteria or the eigenvalue rule, I retained only factors with an eigenvalue greater than 1.0 for further investigation. Table 2 of Appendix D displays the results of the Varimax rotation I performed to aid in the interpretation of this rule. The two-factor solution explained $66.3 \%$ of the variance, with component 1 contributing $36.98 \%$ of the variance, and component 2 contributing 29.3\%. The separation of these components in two was not consistent with the previous literature on engagement, which maintains that these activities should remain in one scale. Using this theoretical perspective, I modified component 1 to include "reading stories to child" and "telling stories to child," while removing the variable "take child to visit relatives," since it conceptually constitutes "responsibility." I verified the Cronbach's alpha to ensure the internal consistency of these variables, and I found that the value of .870 that this scale generates exceeds the recommended value of .7 (Pallant 2001).

I operationalize the dependent variable using a scale composed of seven items, each indicating how many days per week a father engages in certain activities with his child. The seven items are: playing games, singing songs, reading stories, telling stories, playing with toys, hugging the child to show physical affection, and putting the child to bed. Since the total scale multiplies the seven items by seven days in each week, fathers can score a maximum of 49 points, which would indicate that they perform all of the involvement items every day of the week. 
Data were missing in four variables from this scale. According to the Fragile Families Data Help Center, it is possible that a data manager made an error and did not record information for one or more of the cities. As stated earlier, I item mean substituted (IMS) for the missing values, drawing on the method that Marsiglio (1991) used to resolve a similar conflict in his study. This means that I substituted the mean item score for each missing value of a particular item.

\section{Independent Variable Construction}

In studying postindustrial employment configurations, researchers have established a clear line between regular and irregular work activities. Some economists imply that any production of goods and services, legal or illegal, that is left off the official Gross Domestic Product estimates constitutes underground or irregular sector activities (Feige 1989; Frey and Pommerehne 1984; Lubell 1991; Rich 1999; Rich and Kim 2001; Smith 1994). Other researchers have distinguished between legal and illegal underground work. Legal-but-underground activities include off-the-books selfemployment, unreported wages, and untaxed work related to legal goods and services. Specific examples might include unreported revenues earned at garage sales, unlicensed taxi services, and selling homemade items like jewelry, etc. Meanwhile, illegal underground activities include trading stolen goods, drug dealing and drug manufacturing, fraud, and prostitution (Schnieder and Enste 2000). Recently, several sociologists have established a difference between the two types of underground work (Anderson 1998; Venkatesh 2000). For example, in his study of a Chicago housing project, Venkatesh (2000) labeled all underground activity as "hustles" but made a distinction between legitimate and illegitimate hustling. He found that illegitimate 
hustles included activities like narcotic and drug trafficking, racketeering, prostitution, and bribing police and government officials, because they jeopardized public safety or negotiated public space.

Drawing on these conceptions, the three primary work variables in the regression capture the number of hours that fathers worked each week in the regular economy, the number of hours each week they spent hustling, and the number of hours each week they worked off-the-books/underground. I operationalized regular work using the survey item "My next few questions are about your current/most recent job. How many hours (do/did) you usually work per week at (this/that) job? Include regular overtime hours." Next, I operationalized hustles using the following codebook item: "About how many hours per week did you [sell or deliver drugs, engage in prostitution, or do other kinds of hustles]?" Finally, I tabulated off-the-books work using the item, "About how many hours per week did you spend [off-the-books or under the table work, [work in own business underground], [do anything else off-the-books to earn money]?"1

Since personal characteristics may affect father involvement ${ }^{3}$, I also incorporated variables related to fathers' demographic attributes, educational attainment, cohabitation status, and mother-father relations. Using SPSS, I transformed items into dummy variables before incorporating them into the regression models. The demographic independent variables include race/ethnicity, expressed as African American, Latino, and white (reference category), and father's age as a continuous variable. I measured fathers' educational attainment by assessing whether the father graduated from college or graduate school, attended some college or technical school, graduated from high school, or did not graduate from high school (reference category). I assessed cohabitation using 
three dummy variables indicating whether the father cohabits with his child and his child's mother, whether he cohabits sometimes, or whether he does not cohabit (reference category). Finally, I measure mother-father relations with an item asking whether the father describes his relationship with the child's mother as just friends, divorced, romantically involved but not married, married, or no relationship (reference category).

\section{Analytical Strategy}

I analyzed the data to examine the effects of fathers' employment, demographic, and social attributes on their involvement with their children. The data analysis includes descriptive statistics, bivariate correlation, and multivariate regression. In the first phase, I gathered means and standard deviations for all the variables I used in this analysis so I could understand the variance of the characteristics under study. Appendix A displays these results. In the second phase, I created a bivariate correlation matrix to examine the relationship between each independent and dependent variable. I display these results in Appendix B. Finally, I assessed the impact of all the independent and control variables together using Ordinary Least Squares regression analysis (OLS). I chose to use OLS for three reasons. First, because this regression technique allows me to evaluate how much the other independent variables in this study contribute to $\mathrm{R}^{2}$, after hours worked contribute its share to predicting father involvement (Tabachnick and Fidell 1996).

Before I used OLS to make inferences about my data, I verified that the data satisfied several assumptions. First, I ensured that my data have a relatively normal distribution by examining a scatterplot. I found curvilinearity among some variable. Though this can weaken my analysis somewhat, it cannot invalidate it (Tabachnick and Fidell 1996). Tabachnick and Fidell (1996) maintain that a curvilinear relationship 
between an independent and a dependent variable is a perfectly legitimate relationship, but it is not completely captured by a linear correlation coefficient. ${ }^{4}$ Third, I found no evidence of multicollinearity after inspecting "Tolerance" values in the table labeled "Coefficients," since all of the values were a respectable distance from zero (usually at least .9).

This regression analysis contains five models. Model 1 tests the first three hypotheses by establishing a baseline set of results that include only the key independent variables and hours per week fathers spent doing regular work, illicit hustles, and off-thebooks/underground work. Model 2 begins to answer the research questions, first highlighting the effects of demographic factors like father's age and race/ethnicity on involvement. The independent variables in the second model include African American and Latino, with white being the reference category. The second model also includes fathers' ages, as a continuous variable. Model 3 is the same as Model 2, but adds educational attainment; the reference category was "did not complete high school." The addition of the educational attainment variables answers research questions about the effects of fathers' educational attainment on involvement with their children. Model 4 is the same as Model 3, but adds cohabitation variables to establish the role of cohabitation in father involvement. The reference category in Model 4 is "does not cohabit." Model 5 is the final regression model. It contains the same variables in the previous Models, and adds the variables about mother-father relations, measured as just friends, divorced or separated, romantically involved, or married, (no relationship between mother and father is the reference category). 


\section{CHAPTER 4}

\section{RESULTS}

In this chapter, I examine the way inner city fathers' employment configurations affect involvement with their young child. I begin this analysis by examining the means and standard deviations for each variable in the multivariate regression. I display these results in Appendix B. I follow the analysis of the descriptive statistics by examining the significant correlations between each pair of variables to understand the degree of their relationship. I present these relationships in the correlation matrix in Appendix C. Finally, the regression in Appendix D extends the bivariate analysis to consider multiple factors that predict father involvement, rather than simply correlate with father involvement. I theoretically "step in" each set of independent variables in five models in the OLS regression analysis.

\section{Descriptives}

The table in Appendix B presents the means and standard deviations for father involvement, and each of the independent variables for the 3,107 fathers in this nationally representative sample. The first set of means and standard deviations refer to the dependent variable, father involvement. I follow this section by describing the various hours fathers worked in each employment sector, as well as the demographics, educational attainment, cohabitation, and mother-father relationships in this sample.

As I described in Chapter 4, I constructed the seven-point father involvement index using theoretical and statistical procedures. The first row in Appendix B shows 
that fathers in this sample scored an average of 29 out of a possible score of $49^{5}$. Similarly, rows two through four and row eight indicate that fathers reported putting their child to bed, hugging their child, playing toys with their child, and playing games with their child on average about five days each week. Meanwhile, fathers reported singing songs or telling nursery rhymes to their child an average of four days each week, which is shown in row 7 of the table. Finally, these fathers reported that they read and tell stories to their child an average of three days each week, as rows five and six indicate. Overall, Appendix B shows that fathers usually focused their involvement on playful and affectionate activities rather than academic-related endeavors, like reading to their child.

Appendix B also presents information about fathers' demographic backgrounds, educational attainment, cohabitation, and the nature of the relationship between mother and the father. The second category of the table marked "Demographic Attributes" shows the racial and ethnic diversity of the fathers in this sample. According to the table, people of color disproportionately compiled the sample. African Americans made up about $47 \%$ of the sample, followed by Latinos (29\%) and whites (24\%). Furthermore, the average age for fathers in this sample was about 29 years old. The category of the table marked "Educational Attainment" offers that the majority of fathers in this study had low levels of educational attainment. In fact, more than two-thirds of the fathers finished only high school or dropped out of high school, and about one-third went on to college or actually finished college, which is fairly high compared to all men in the United States in $1999^{6}$. To break these down further, $33 \%$ of fathers did not complete high school, while another $33 \%$ of the fathers completed high school or earned a GED. Of the fathers who finished high school and pursued education, $23 \%$ finished some 
college or completed technical school, and about $11 \%$ reported graduating from college or pursuing additional studies beyond a Bachelor's degree.

The table in Appendix B also shows that most of the fathers in this sample cohabited, at least to some degree, with their child and the child's mother. In fact, $70 \%$ of fathers in this sample cohabited always with the mother of their child, while $15 \%$ of the sample cohabited only sometimes and another $15 \%$ did not cohabit. Appendix B also displays the differences among fathers in their relationship with the child's mother. The final section of Appendix B shows that the majority of the fathers in this study were either romantically involved or married to their child's mother. These fathers constituted an overwhelming $80 \%$ of the sample. While $44 \%$ reported being romantically involved but not married, $36 \%$ of fathers reported being married to their child's mother. In contrast, the fathers who described their relationship with the child mother as merely friendship, or reported being divorced or having no contact with the child's mother represented a minority of the cases in this study. Of these fathers, $14 \%$ of the fathers described their mother-father relationship as just a friendship, $1 \%$ claim to be divorced or legally separated, and 5\% reported not having a relationship with the child's mother.

\section{Bivariate Correlations}

The table in Appendix C displays the bivariate correlations between variables in this analysis. The cells in the table contain the Pearson product-moment correlation coefficient (Pearson's $r$ ), followed by an asterisk when the coefficient is statistically significant below the .05 level. 
Several correlations related to father involvement are worth highlighting. First, hustling was significantly and negatively correlated with father involvement $(r=-.104)$. This correlation supported my hypothesis that hustles contributed to lower levels of involvement. The correlation matrix provides a few explanations about why hustling correlated negatively with father involvement. First, hustling correlated with variables that did not share a positive relationship with involvement. For example, hustling was positively correlated with not cohabiting with the child and the child's mother $(r=.117)$, and research showed that nonresidential fathers tended to be less involved with their children than fathers who cohabit (Johnson 2000). Second, hustling negatively correlated with variables that were positively associated with involvement. For example, hustling negatively correlated with marriage, a variable that was positively associated with involvement $(\mathrm{r}=-.079)$ and tended to be a positive predictor of father involvement (Manning and Lichter 1996).

The correlation matrix in Appendix $\mathrm{C}$ also presents significant associations involving race/ethnicity. One notable correlation was that being African American was significantly and negatively correlated with father involvement $(\mathrm{r}=-.125)$. This association was probably due to work, education, and cohabitation. To elaborate, being African American was negatively associated with regular work $(r=-.104)$, with college graduation $(\mathrm{r}=-.191)$, and cohabitation with mother and child $(\mathrm{r}=-.293)$, all of which were positively and significantly correlated with father involvement. Third, as I alluded to in the first association between hustling and involvement, fathers who cohabit were more involved (Johnson 2000). The Pearson's $r$ values in the correlation matrix appeared quite large between cohabitation and involvement. Consistent with the existing literature 
(Carlson et al. 2005; Carlson and McLanahan 2002), these coefficients demonstrated that not cohabiting with the child and the child's mother was significantly and negatively associated with father involvement $(r=-.227)$, but cohabiting was positively and significantly associated with father involvement $(\mathrm{r}=.529)$. In addition to residential fathers having day-to-day exposure to their children, cohabitation correlated positively with other variables like regular work $(r=.122)$, graduating from college $(r=.172)$, romantic involvement $(\mathrm{r}=.128)$, and marriage $(\mathrm{r}=.472)$, all of which were positively correlated with father involvement. Fourth, just maintaining friendship with the child's mother was negatively correlated with father involvement $(\mathrm{r}=-.328)$. These variables were negatively correlated possibly because being just friends with the child's mother was negatively correlated with being white $(r=-.145)$, graduating from college $(r=-$ $.104)$, and cohabiting $(\mathrm{r}=-.604)$. Finally, being white was positively and significantly

correlated with father involvement $(\mathrm{r}=.114)$. Being white and involved stemmed in part from the fact that being white was correlated with graduating from college $(r=.369)$, cohabitation $(\mathrm{r}=.201)$, and marriage $(\mathrm{r}=.319)$ in this sample. Being white was also negatively correlated with variables like not graduating high school $(\mathrm{r}=-.205)$ and maintaining only a friendship between mother and father $(r=-.145)$.

\section{Regression Results}

The final part of my analysis presents the models showing the effects of work configurations and other control variables on father involvement. The cells in the regression table in Appendix D report the unstandardized beta coefficients and standard errors to demonstrate how the number of hours worked in each employment sector affect father involvement for the total sample. An asterisk accompanies statistically significant 
coefficients, depending upon each coefficient's p-value. The adjusted $\mathrm{R}$ squared value at the bottom of each column shows the percentage of father involvement that is explained by the independent variables in each model.

The time fathers spent working in specific kinds of employment played a significant role in predicting father involvement. Model 1 in the regression table demonstrateed that the number of hours fathers worked in regular employment coincided with positive levels of father involvement $(b=.099, \mathrm{p}<.001)$. In contrast, Model 1 also showed that the time fathers spent hustling was associated with lower levels of father involvement $(b=-.104, p<.001)$. Finally, the number of hours fathers worked off-thebooks had no significant positive or negative impact on father involvement. The adjusted $\mathrm{R}$ squared value for Model 1 explained only $2 \%$ of the variance in father involvement. Model 1 illustrated that although fathers working regular jobs tended to be more involved with their children than those who hustled, working off-the-books did not tend to affect the amount of involvement fathers had with their children.

Model 2 denoted that fathers' race/ethnicity and hours spent in some kinds of work significantly affected father-child involvement, but age did not. First, Model 2 showed that compared to being white, being African American negatively predicted father involvement $(b=-.147, p<.001)$. Similarly, being Latino was also negatively associated with father involvement $(b=-.057, \mathrm{p}<.05)$, compared to being white. Age did not significantly predict father involvement in this model. Second, the significant effects of hours worked in regular employment and hours worked hustling remained in Model 2, though the beta coefficients decreased $(b=.078 ; b=-.095)$. As in Model 1, off-the-books work was not a significant predictor. The adjusted R squared changed 
between Model 1 and Model 2 is $.014(\mathrm{p}<.001)$, and the new adjusted $\mathrm{R}$ square value indicated that Model 2 explained 3.4\% of the variance in father involvement. These results showed that being African American or being Latino negatively predicted father involvement, which contradicted the previous research that African Americans were more involved in household work than white fathers regardless of their employment status (Coltrane 2000; Shelton and John 1993). Furthermore, since research showed that African Americans were more strongly oriented with work (Feagin and McKinney 2003) even though African Americans and whites had similar attitudes about work (Hill and Hill 1999), it makes sense that work configurations mediated at least some of their levels of involvement. ${ }^{7}$ Though this finding neither supported nor negate my hypothesis concerning hustles and father involvement, it did contribute to the literature and answer my research question concerning the role of race/ethnicity in explaining father involvement.

Model 3 implied that educational attainment was a significant predictor of father involvement. Using less than a high school diploma as the reference category, graduating from college $(b=.091, p<.001)$, attending some college or technical school $(b=.093, p$ $<.001)$, and having a high school diploma or equivalent $(\mathrm{b}=.091, \mathrm{p}<.05)$ positively and significantly predicted father involvement. Model 3 also showed that the amount of time fathers worked in regular employment still positively predicted levels of father involvement $(\mathrm{b}=.065, \mathrm{p}<.001)$ and that time spent hustling still negatively predicted involvement $(b=.094, p<.001)$, though with decreasing sizes of beta coefficients. Finally, in Model 3, being African American remained a significant negative predictor of father involvement $(b=-.124, p<.001)$, but being Latino no longer significantly 
predicted father involvement. The adjusted R squared changed between Model 2 and Model 3 to $.007(\mathrm{p}<.01)$ and the new Adjusted R Square indicated that Model 3 explained $4.1 \%$ of the variance in father involvement. Even in the presence of these covariates, hours worked in the regular economy and hours spent hustling remained significant predictors of father involvement. Furthermore, not finishing high school was a suppressor variable that removed the significance of being Latino as a predictor of father involvement. ${ }^{8}$ In other words, being Latino and not graduating from high school both predicted father involvement. However, after controlling for not finishing high school, being Latino alone did not significantly predict father involvement.

Model 4 revealed that cohabitation with the child and the child's mother was a significant and positive predictor of father involvement. Compared to "never cohabiting," fathers who cohabited were more involved $(b=.595, \mathrm{p}<.001)$, as were those who cohabited sometimes $(\mathrm{b}=.172, \mathrm{p}<.001)$, though the beta coefficients indicated that cohabiting all the time presented a steeper regression line that cohabiting sometimes. Also, several variables changed in significance in Model 4. With regard to the number of employment hours, the number of hours fathers worked in regular employment no longer significantly predicted father involvement. In contrast, the number of hours spent hustling remained significant, but with a lower beta coefficient (b $=-.050, \mathrm{p}<.01)$ compared to Model 3. The effects of the demographic variables changed significantly between Model 3 and Model 4. While being African American lost significance as a predictor of father involvement and Latino remained insignificant, age became a significantly negative predictor of father involvement $(b=-.065, p<.01)$. Finally, completing college no longer significantly predicted father involvement in Model 
4. Meanwhile, completing some college or technical school $(b=.093, p<.001)$ or graduating high school $(\mathrm{b}=.069, \mathrm{p}<.05)$ remained significant, though with lower beta coefficients. The adjusted R squared change between Model 3 and Model 4 was an overwhelming .274 $(\mathrm{p}<.001)$ and the new adjusted R squared indicated that Model 4 explained $31.5 \%$ of the variance in father involvement. These findings supported research indicating that cohabitation encouraged father presence (Kenney 2004) and involvement (Furstenberg et al. 1983; Seltzer and Bianchi 1988). They also supported research indicating that educational attainment mediated the relationship between variables (Cazenave and Leon 1987; King et al. 2004).

In a few instances the results generated in Model 4 were inconsistent with prior research findings. First, Model 4 did not support the finding that father absence affected father presence less among children of color than among white children (Danziger and Radin 1990). In reality, cohabiting all the time mediated the negative association between being African American and involved ${ }^{8}$. Model 4 supported research indicating that other variables partially mediated the association between race/ethnicity and father involvement (King et al. 2004; Lerman 1993). Second, Model 4 did not support research demonstrating that all forms of employment encouraged father involvement (Coley and Chase-Lansdale 1999; Danziger and Radin 1990; Marsiglio 1991) in part because cohabitation partially mediated the association between regular work and father involvement ${ }^{9}$. This finding partly supported my hypothesis that the number of hours fathers worked in a regular job would positively predict father involvement, though with the modification that cohabiting all the time contributed partly to the positive association. 
Model 5 illustrates how various kinds of mother-father relationships affected paternal involvement. Compared to parents who have no relationship with each other all other mother-father relationships were associated with positive levels of father involvement. Specifically, relationships with the mother that the father characterized as just friends $(\mathrm{b}=.151, \mathrm{p}<.001)$, romantically involved $(\mathrm{b}=.126, \mathrm{p}<.05)$, married $(\mathrm{b}=$ $.118, \mathrm{p}<.05)$, or even divorced or legally separated $(\mathrm{b}=.109, \mathrm{p}<.001)$ each positively predicted father involvement in Model 5. Furthermore, Model 5 presented no new changes in significance levels for the relationship from Model 4. Model 5 showed that the number of hours spent hustling remained significant through all of the statistical models in this equation $(b=-.043, p \leq .01)$. Furthermore, with regard to demographic variables, race/ethnicity did not predict father involvement in Model 5, and age remained a significant negative predictor of father involvement $(b=-.068, p<.01)$. Educational attainment continued to positively predict father involvement at the high school graduate level $(b=.052, \mathrm{p}<.05)$ and for fathers with some college or technical school $(b=.093, p$ $<.01)$. Finally, the cohabitation variables remained highly significant $(\mathrm{p}<.001)$ and the beta coefficient increased so that cohabiting $(\mathrm{b}=.632)$ and cohabiting sometimes $(\mathrm{b}=$ .188) positively predicted father involvement more strongly in Model 5 than previously. The adjusted R squared change between Model 4 and Model 5 is $.013(\mathrm{p}<.001)$ and the new adjusted R square indicated that Model 5 explains $32.8 \%$ of the variance in father involvement. 


\section{CHAPTER 5}

\section{DISCUSSION AND CONCLUSION}

The first goal of this research was to ascertain whether differences in fathers' employment configurations affected their levels of involvement in fragile families. I found that fathers who spent time doing illicit hustles were likely to have problematic relationships with their children, which supports my third hypothesis. With regard to Hypotheses 1 and 2, the regression results generated no evidence supporting my hypotheses that hours worked in regular employment or hours worked off-the-books would positively predict levels of paternal involvement. Instead, these variables generated no observed effect after four models ${ }^{10}$. This conclusion advanced the current literature by filling two research gaps. First, it provided a study partly explaining the dynamics causing nurturing behavior among young fathers (Danziger and Radin 1990). It also presented the first quantitative study investigating the effects of illegal work on father involvement. Second, my regression results contradicted the research claim that increasing fathers' economic resources encouraged paternity (Danziger and Radin 1990; Marsiglio 1991). Contrary to the existing literature, my regression results showed that fathers' levels of involvement fluctuated even when they were fully employed, particularly among the fathers who were hustling. Finally, it cleared the ambiguity that hustling might be a legitimate way to support one's family. Despite qualitative accounts that highlight the good intentions of some fathers who hustle (Edin et al. 1998; PattilloMcCoy 2000; Schlosser 2003), my regression results showed that illegal work was 
problematic because the fathers who engaged in it tended to report being less involved with their children.

The second goal of this thesis was to answer research questions about the role of educational attainment in father involvement. The regression results indicated that educational attainment affected father involvement directly and as a mediator. In the first instance, fathers who completed high school and some college or technical school associated with higher levels of involvement with their children. My regression results partly upheld research claims that better educated fathers were more involved with their children than less educated (Flouri and Buchanan 2003; Volling and Belsky 1991), but with some modification. It was true that fathers who finished high school were likely to be more involved than fathers who did not, but the difference between completing high school and some college/technical school was slight; actually completing college exhibited no significant effect by the end of the regression. Ultimately, the regression results indicated that increasing levels of educational attainment as a direct influence on paternal involvement had a diminishing effect. Nevertheless, educational attainment was an important predictor of father involvement, particularly for Latinos. After all, once I controlled for graduating high school, being Latino no longer predicted father involvement. This finding answered my research question concerning educational attainment by showing the relevance of this variable in predicting father involvement.

The third goal of this study was to assess the role of race/ethnicity and age in father involvement. Drawing on evidence from the regression, it was evident that other variables mediate the relationship between race/ethnicity and father involvement in fragile families. My results generated two examples that support this conclusion. In the 
first instance, controlling for cohabitation removed the significance of African American as negative predictor of father involvement. Similarly, controlling for educational attainment removed the significance of being Latino as a negative predictor of father involvement. By the end of the regression, being African Americans or Latino generated no observed effect on father involvement. This important finding contributed to the literature in two ways. First, it supported research concluding that race and ethnicity significantly predicted father involvement when mediated by other variables (King et al. 2004). Accordingly, these results contradicted the empirical literature maintaining that white fathers were more involved than fathers of color (Bartz and Levine 1978) or that fathers of color were more involved than white fathers (McLoyd et al. 2000; Rubin 1994). This result answered my research question concerning race/ethnicity because it demonstrated that the importance of other variables in mediating the effect of race/ethnicity on paternal involvement.

The fourth aim of this thesis was to examine the role that cohabitation and mother-father relations played in father involvement. Even though every type of nonmarital mother-father relationship significantly and negatively correlated with father involvement, the regression results showed that all of the nonmarital relationships significantly and positively predict father involvement. This finding suggested that marriage was only one of many ways to encourage paternal involvement in fragile families. The regression results also showed that levels of father-child involvement tended to be highest in cases where the relationship between mother and father was a nonromantic friendship, rather than romantic, married, or divorced. This conclusion might baffle marriage-minded researchers, since it may not sit well with long-standing 
efforts to encourage legal marriage as the universal remedy for fragile families. I offer two logical conclusions from the existing literature to bolster this finding. First, I theoretically operationalized my dependent variable, father involvement, by measuring engagement activities, rather than financial provisions or presence. Since a large portion of the literature focused on the economic state of children in single parent households, researchers tended to focus efforts on marriage as the best means to insure a family's economic wellbeing. Second, research showed that men prioritize their paternal obligations differently. Fathers who sustained non-romantic friendships with their child's mother tended to emphasize providing direct childcare (Kalil 2003). Meanwhile, fathers who were romantically involved with their child's mother and cohabited usually concentrated their efforts on ensuring the family's financial well-being (Johnson 2000; Kalil 2003). If they eventually married, these fathers were more likely to have a job, work significantly more hours each week, and work more weeks each year than other fathers (Rich 1999). They were usually prone to marriage conflict as well (Kalil 2003). This unique finding was consistent with the existing literature.

Currently, no existing research discusses whether fathers' role perceptions exist before the relationship or if the mother-father relationship is a transforming mechanism whereby men assume new obligations because of role conflict. What we do know is that the fathers in fragile families that have some relationship with their child's mother are likely to be involved with their child one year after birth. Furthermore, the fathers in this study who have nonromantic relationships with the child's mother report the highest levels of father involvement. 
This thesis presented another surprising conclusion: divorced or separated fathers were likely to have high levels of involvement with their children compared to fathers who had no relationship with the child's mother. There were a few reasons why this makes sense. First, divorced or legally separated fathers constituted only $1 \%$ of fathers in this study. The members of this unique subgroup probably had much in common since they selected into marriage, possibly cohabited, used legal means to dissolve their marriage, and may pay child support accordingly. Drawing on previous literature that identified that paying child support, visiting, and childrearing tended to be corresponding activities (Seltzer 1991), it was likely that the divorced fathers in this sample who participated in even one of these activities were likely to perform other and increase their involvement. Second, not all marriages end acrimoniously. If these fathers' marriages ended on somewhat benevolent terms and each person fulfills her or his part of the relationship, it makes sense that fathers reported positive levels of involvement with their child and that fathers' ex-wives did not hamper involvement accordingly. Finally, cases where a father had sole custody of his child would obviously increase involvement ${ }^{11}$.

My research has clear policy implications since paternal involvement in fragile families has recently become the target of social policy under the Fathers Count Act (FCA). This TANF-style piece of legislation carried three main objectives: to promote marriage, successful parenting, and teach financial responsibility by encouraging fathers and their families to avoid or leave cash welfare that was provided under TANF. My results indicated that these FCA objectives could potentially counteract the wellbeing of fragile families. First, the regression results challenged the FCA assumption that marriage was the best way to promote successful parenting in fragile families since all 
nonmarital mother-father relationships positively predicted father involvement.

Furthermore, other important variables like educational attainment and cohabitation status mediated father involvement for entire race and ethnic groups in my sample.

Second, my research shows that it was problematic for the Fathers Count Act to assume that inner city fathers were financially irresponsible because their children receive public aid. Instead, the overwhelming number of hours fathers spent in the various sectors of the labor market in this study, and the supporting evidence from the literature (Edin et al. 1998; Edin and Nelson 2001; Pattillo-McCoy 2000) showed that some fathers went to great lengths to support their fragile families. It is true that fathers must be accountable for personal actions like the decision to pay child support, but they cannot be responsible for the structural factors that hamper their incomes, like the economic upheaval brought about during deindustrialization, the stagnant minimum wage, and the limited opportunities offered in the local labor market. In fact, many poor fathers who the Fathers Count Act encourages to leave public assistance actually "persist in an economy where their value is so low that they can barely sustain themselves, much less their families" (Edin et al. 1998).

If social policy initiatives really want to encourage father involvement in fragile families, the evidence in this thesis offers several suggestions. First, policy initiatives should attempt to curb hustles as a means of economic sustenance, because hustles negatively predict father involvement and the correlation matrix shows that hustles are negatively associated with father involvement. Policy makers should focus on creating sustained legal employment opportunities with living wages and benefits, partly because fathers' decisions to do illegal or legal work is likely to be an economic trade-off based 
on wages (Levitt and Venkatesh 1998). Moreover, research has shown that dealing drugs offers relatively low pay for the risk that dealers invest (Levitt and Venkatesh 1998). Enhance labor market opportunities are likely to curb hustling among fathers in fragile families.

Cohabitation and mother-father relations are important determinants of father involvement, and should be targeted with caution. Marriage is not a cure for all social problems (Lichter et al. 2003), and my regression results indicate that marriage is not the best or only mother-father relationship to encourage paternal involvement. Since regular hours worked positively predict both cohabitation and marriage ${ }^{12}$, creating sustainable jobs is likely to promote stronger and more economically self-sufficient families (Mincy and Huang 2002). After all, plenty of research shows that the depletion of jobs has produced father-absent homes (Anderson 1998; Danziger and Radin 1990; PattilloMcCoy 2000; Stier and Tienda 1993; Sullivan 1989, 1993; Wilson 1980, 1996) marriage produce jobs.

Until legitimate employment opportunities proliferate for low-income fathers who are trying to take care of their fragile families, hustling is likely to remain a lucrative way to make ends meet. After all, many inner city fathers are preoccupied with their failures as good providers to their children, and many more "can't imagine life without them," so they are likely to do whatever it takes to provide for their fragile families (Edin et al. 1998). And in the process of making a living, many of these fathers will unknowingly compromise the very relationship with their child that they hold so dear. 


\section{Limitations to This Study}

There are four limitations to this study. First, in multiple instances, I mean substituted values because of missing data. In particular, the dependent variable I constructed through factor analysis was missing $10 \%$ of its values in four of the seven

component items. After contacting the Fragile Families Data Center, I discovered that these missing values resulted from errors in the data set, which neither the Fragile Families Data Center nor I can correct at this time. Drawing on Marsiglio's (1991) method to remedy an almost identical situation, I item mean substitute missing values using SPSS.

The second limitation to my research concerns the accuracy of responses by participants to some sensitive questions, especially about participation in the illicit underground economy. After running frequencies, I found that about $20 \%$ of respondents admit to working off-the-books, $11 \%$ report that they work in their own business "offthe-books," and fewer than $8 \%$ earn money in other underground ways. I was particularly surprised to discover that slightly less than $3 \%$ percent of the entire sample earned money through hustling. Since the battery of questions probing illicit underground work are sensitive and this questionnaire was administered face-to-face, some respondents are likely to have provided dishonest but socially desirable answers (Babbie 2001). Since no other organization estimates nationally-representative statistics on hustling in fragile families, it is currently not possible compare the small population in this sample with another nationally representative population.

Third, I use theoretical logic to argue that the independent variables cause the dependent variable. Since cross-sectional regression equations do not contain lag 
variables, it is not possible to statistically determine whether the independent variable causes the dependent variable or visa versa. As the Fragile Families data managers continue to collect data, future studies could use a longitudinal technique to better determine statistical causality.

A final limitation to this study is that it presents no comparison group of stable income families. The Fragile Families and Child Wellbeing surveys a group of lowincome families who had a child outside of marriage. The respondents lived in U.S. cities of 200,000 or more in 1998. Future studies should compare groups with varying socioeconomic statuses because fathers from all socioeconomic backgrounds engage in illegal work to make ends meet. A future study would establish if the effects I found apply to all fathers. 


\section{APPENDIX A:}

\section{RESULTS FOR FACTOR ANALYSIS}

Total Variance Explained for Components of Proposed Father Involvement Index

\begin{tabular}{ccccccc}
\hline Component & \multicolumn{3}{c}{ Initial Eigenvalues } & \multicolumn{3}{c}{ Sums of Squared Loadings } \\
\hline & Total & $\begin{array}{c}\text { \% of } \\
\text { Variance }\end{array}$ & $\begin{array}{c}\text { Cumulative } \\
\%\end{array}$ & Total & $\begin{array}{c}\text { \% of } \\
\text { Variance }\end{array}$ & $\begin{array}{c}\text { Cumulative } \\
\%\end{array}$ \\
1 & 4.247 & 53.090 & 53.090 & 4.247 & 53.090 & 53.090 \\
2 & 1.055 & 13.190 & 66.280 & 1.055 & 13.190 & 66.280 \\
3 & .783 & 9.784 & 76.064 & & & \\
4 & .522 & 6.529 & 82.594 & & & \\
5 & .477 & 5.959 & 88.553 & & & \\
6 & .324 & 4.048 & 92.601 & & & \\
7 & .318 & 3.970 & 96.572 & & & \\
8 & .274 & 3.428 & 100.00 & & \\
\hline \multicolumn{7}{l}{ Extraction Method: Principal Component Analysis }
\end{tabular}

Varimax Rotation of Two Factor Solutions for Involvement Items

\begin{tabular}{lcc}
\hline Item & Component 1 & Component 2 \\
\hline Hugging Child & .828 & \\
Playing Games with Child & .752 & .385 \\
Playing Toys with Child & .740 & .373 \\
Putting Child to Bed & .725 & \\
Taking Child to Relatives & .615 & .872 \\
Telling Stories to Child & & .866 \\
Reading Stories to Child & & .634 \\
Singing Songs to Child & .441 & 29.303 \\
\% of Variance Explained & 36.977 & 66.280 \\
Cumulative \% & 36.977 & \\
\hline Extraction Method: Principal Component Analysis & \\
\hline
\end{tabular}




\section{APPENDIX B:}

\section{DESCRIPTIVE STATISTICS}

Means and Standard Deviations for Father Involvement and Independent Variables

\begin{tabular}{|c|c|c|}
\hline Variables & Mean & Standard Deviation \\
\hline Father Involvement Index & 29.14 & 7.24 \\
\hline Put child to bed & 4.67 & 2.59 \\
\hline Hugged child & 5.98 & 2.16 \\
\hline Played toys with child & 5.07 & 2.47 \\
\hline Told stories to child & 3.00 & 2.65 \\
\hline Read stories to child & 2.91 & 2.56 \\
\hline Sang songs to child & 4.03 & 2.68 \\
\hline Played games with child & 5.16 & 2.39 \\
\hline \multicolumn{3}{|l|}{ Demographic Attributes } \\
\hline \multicolumn{3}{|l|}{ Race/Ethnicity } \\
\hline White & .24 & .42 \\
\hline African American & .47 & .50 \\
\hline Latino & .29 & .45 \\
\hline Age & 29.14 & 7.24 \\
\hline \multicolumn{3}{|l|}{ Education } \\
\hline Less than High School & .33 & .47 \\
\hline High school/GED & .33 & .47 \\
\hline Some college/tech school & .23 & .42 \\
\hline Bachelor's/grad school & .11 & .32 \\
\hline \multicolumn{3}{|l|}{$\begin{array}{l}\text { Cohabitation with } \\
\text { mother/child }\end{array}$} \\
\hline Almost always cohabits & .70 & .45 \\
\hline Sometimes cohabits & .15 & .21 \\
\hline Never Cohabits & .15 & .22 \\
\hline \multicolumn{3}{|l|}{ Marital status with mother } \\
\hline Married to mother & .36 & .48 \\
\hline Romantic with mother & .44 & .50 \\
\hline Separated from mother & .01 & .11 \\
\hline Friends with mother & .14 & .34 \\
\hline No Relationship & .05 & .22 \\
\hline $\mathrm{N}=3,107$ & & \\
\hline
\end{tabular}




\section{APPENDIX C:}

\section{BIVARIATE CORRELATION MATRIX}

Correlations for Father Involvement and Independent Variables

\begin{tabular}{|c|c|c|c|c|c|c|c|c|c|c|}
\hline & 1 & 2 & 3 & 4 & 5 & 6 & 7 & 8 & 9 & 10 \\
\hline 1.RegularHours Worked & 1.00 & & & & & & & & & \\
\hline 2.Hours Hustling & $-.038^{*}$ & 1.00 & & & & & & & & \\
\hline 3.Hours worked off-the-books & -.028 & $.089^{*}$ & 1.00 & & & & & & & \\
\hline 4. African American & $-.134^{*}$ & $.088^{*}$ & $.037 *$ & 1.00 & & & & & & \\
\hline 5. Latino & $.052 *$ & $-.042 *$ & $-.043^{*}$ & $-.610^{*}$ & 1.00 & & & & & \\
\hline 6. White & $.103^{*}$ & $-.059 *$ & .002 & $-.538^{*}$ & $-.339 *$ & 1.00 & & & & \\
\hline 7. Father's Age & $.093^{*}$ & $-.054 *$ & -.024 & $-.056^{*}$ & $-.104 *$ & $.178^{*}$ & 1.00 & & & \\
\hline 8. College Grad & $.099^{*}$ & -.030 & $-.052^{*}$ & $-.191^{*}$ & $-.133^{*}$ & $.369^{*}$ & $.286^{*}$ & 1.00 & & \\
\hline 9. Some College/Tech & $.055^{*}$ & -.024 & .002 & .000 & $-.053^{*}$ & $.056^{*}$ & $.097^{*}$ & $-.197^{*}$ & 1.00 & \\
\hline 10. HS Diploma/GED & .017 & .009 & $.055^{*}$ & $.172 *$ & $-.103^{*}$ & $-.095^{*}$ & $-.076^{*}$ & $-250 *$ & $-384 *$ & 1.00 \\
\hline 11. NotHS grad & $-.134 *$ & .033 & -.022 & $-.042 *$ & $.240^{*}$ & $-.205^{*}$ & $-.204^{*}$ & $-249^{*}$ & -383 & $-.486^{*}$ \\
\hline 12. Cohabit & $.122^{*}$ & $.097^{*}$ & -.026 & $-.293 *$ & $.137^{*}$ & $.201 *$ & $.163^{*}$ & $.172^{*}$ & $.044^{*}$ & $-.066^{*}$ \\
\hline 13. Cohabit sometimes & -.022 & .005 & .007 & $.109 *$ & $-.048^{*}$ & $.078^{*}$ & -.031 & $-.063^{*}$ & -.034 & $.051^{*}$ \\
\hline 14. Do notcohabit & -.028 & $.117^{*}$ & $.040^{*}$ & $.107^{*}$ & $-.045^{*}$ & $-.079 *$ & $-.062^{*}$ & $-.072^{*}$ & -.022 & .030 \\
\hline 15. Just Friends & $-.090 *$ & .025 & .007 & $.201^{*}$ & $-.088^{*}$ & $-.145^{*}$ & $-.113^{*}$ & $-.104 *$ & $-.040^{*}$ & .031 \\
\hline 16. Divorced & -.009 & -.013 & .012 & -.031 & -.015 & $.053^{*}$ & -.003 & -.021 & .031 & -.026 \\
\hline 17. Romantically Involved & -.025 & $.042^{*}$ & .034 & $.116^{*}$ & $.051^{*}$ & $-.192 *$ & $-.164^{*}$ & $-.247^{*}$ & $-.060 *$ & $.093^{*}$ \\
\hline 18. Married & $.119 *$ & $-.079 *$ & $-.039 *$ & $-.301 *$ & $.036^{*}$ & $319 *$ & $.284^{*}$ & $.359 *$ & $.080^{*}$ & $-.125^{*}$ \\
\hline 19. No Relationship & $-.052^{*}$ & $.045^{*}$ & -.007 & $.090^{*}$ & $-.044 *$ & $-.061 *$ & $-.070^{*}$ & $-.052 *$ & .004 & .027 \\
\hline 20. Involvement Index & $.090^{*}$ & $-.104^{*}$ & .007 & $-.125 *$ & .032 & $.114 *$ & $.052 *$ & $.092^{*}$ & $.054 *$ & -.017 \\
\hline \multicolumn{11}{|l|}{ Continued } \\
\hline & 11 & 12 & 13 & 14 & 15 & 16 & 17 & 18 & 19 & 20 \\
\hline \\
\hline \multirow{2}{*}{\multicolumn{11}{|c|}{$\begin{array}{l}\text { 2.Hours Hustling } \\
\text { 3.Hours worked off-the-books }\end{array}$}} \\
\hline & & & & & & & & & & \\
\hline \multicolumn{11}{|l|}{ 4. African American } \\
\hline \multicolumn{11}{|l|}{ 5. Latino } \\
\hline \multicolumn{11}{|l|}{ 6. White } \\
\hline \multicolumn{11}{|l|}{ 7. Father's Age } \\
\hline \multicolumn{11}{|l|}{ 8. College Grad } \\
\hline \multicolumn{11}{|l|}{ 9. SomeCollege/Tech } \\
\hline \multicolumn{11}{|l|}{ 10. HS Diploma/GED } \\
\hline 11. Not HS grad & 1.00 & & & & & & & & & \\
\hline 12. Cohabit & $-.090^{*}$ & 1.00 & & & & & & & & \\
\hline 13. Cohabit sometimes & .022 & $-.329 *$ & 1.00 & & & & & & & \\
\hline 14. Do not cohabit & $.039 *$ & $-.360^{*}$ & $-.052^{*}$ & 1.00 & & & & & & \\
\hline 15. Just Friends & $.075^{*}$ & $-.604 *$ & $-.087^{*}$ & $-.095^{*}$ & 1.00 & & & & & \\
\hline 16. Divorced & .012 & $-.166^{*}$ & -.024 & -.026 & $-.044 *$ & 1.00 & & & & \\
\hline 17. Romantically Involved & $.128^{*}$ & $.166^{*}$ & $.219^{*}$ & $.252 *$ & $-.351^{*}$ & $-.097^{*}$ & 1.00 & & & \\
\hline 18. Married & $-.190^{*}$ & $.472^{*}$ & $-.134^{*}$ & $-.160 *$ & $-.298 *$ & $-.082 *$ & $-.659 *$ & 1.00 & & \\
\hline 19. No Relationship & .005 & $-.358^{*}$ & $-.051^{*}$ & $-.056^{*}$ & $-.094 *$ & -.026 & $-.208^{*}$ & $-.177 *$ & 1.00 & \\
\hline 20. InvolvementIndex & $-.095^{*}$ & $.529 *$ & -.017 & $-.227^{*}$ & $-.328 *$ & $-.045^{*}$ & $.149 *$ & $.244^{*}$ & $-306^{*}$ & 1.00 \\
\hline
\end{tabular}




\section{APPENDIX D:}

\section{OLS REGRESSION ANALYSIS}

OLS Regression Displaying the Effects of Independent Variables on Father Involvement

\begin{tabular}{|c|c|c|c|c|c|}
\hline Independent variables & Model 1 & Model2 & Model 3 & Model 4 & Model 5 \\
\hline Hrs/wk Regular Work & $\begin{array}{l}.099 * * * \\
(.025)\end{array}$ & $\begin{array}{l}.078 * * * \\
(.025)\end{array}$ & $\begin{array}{l}.065^{* * *} \\
(.025)\end{array}$ & $\begin{array}{c}.032 \\
(.021)\end{array}$ & $\begin{array}{c}.031 \\
(.021)\end{array}$ \\
\hline Hrs/wk IllicitHustles & $\begin{array}{l}-.104^{* * * *} \\
(.081)\end{array}$ & $\begin{array}{l}-.095 * * * \\
(.081)\end{array}$ & $\begin{array}{l}-.094 * * * \\
(.081)\end{array}$ & $\begin{array}{l}-.050 * * \\
(.069)\end{array}$ & $\begin{array}{l}-.043^{*} \\
(.068)\end{array}$ \\
\hline Hrs/wk Off-the-books & $\begin{array}{c}.018 \\
(.023)\end{array}$ & $\begin{array}{l}.020 \\
(.023)\end{array}$ & $\begin{array}{c}.021 \\
(.023)\end{array}$ & $\begin{array}{c}.021 \\
(.019)\end{array}$ & $\begin{array}{c}.019 \\
(.019)\end{array}$ \\
\hline African American & & $\begin{array}{l}-.147^{* * * *} \\
(.815)\end{array}$ & $\begin{array}{l}-.124^{* * * *} \\
(.856)\end{array}$ & $\begin{array}{c}.020 \\
(.740)\end{array}$ & $\begin{array}{c}.022 \\
(.746)\end{array}$ \\
\hline Latino & & $\begin{array}{l}-.057^{*} \\
(.925)\end{array}$ & $\begin{array}{l}-.025 \\
(.970)\end{array}$ & $\begin{array}{l}-.029 \\
(.819)\end{array}$ & $\begin{array}{l}-.028 \\
(.814)\end{array}$ \\
\hline Age & & $\begin{array}{l}.027 \\
(.045)\end{array}$ & $\begin{array}{l}.007 \\
(.046)\end{array}$ & $\begin{array}{l}-.065^{* *} \\
(.039)\end{array}$ & $\begin{array}{l}-.068^{* * * *} \\
(.040)\end{array}$ \\
\hline$\geq$ College & & & $\begin{array}{l}.091^{* * * *} \\
(1.209)\end{array}$ & $\begin{array}{c}.030 \\
(1.027)\end{array}$ & $\begin{array}{c}.034 \\
(1.054)\end{array}$ \\
\hline Some College/ Tech School & & & $\begin{array}{l}.093^{* * * *} \\
(.904)\end{array}$ & $\begin{array}{l}.059^{* *} \\
(.765)\end{array}$ & $\begin{array}{l}.062^{* *} \\
(.764)\end{array}$ \\
\hline HS Grad/GED & & & $\begin{array}{l}.069 * \\
(.820)\end{array}$ & $\begin{array}{l}.048^{*} \\
(.693)\end{array}$ & $\begin{array}{l}.052 * \\
(.688)\end{array}$ \\
\hline Cohabiting & & & & $\begin{array}{l}.595^{* * * *} \\
(.662)\end{array}$ & $\begin{array}{l}.632^{* * * *} \\
(1.238)\end{array}$ \\
\hline Cohabiting Sometimes & & & & $\begin{array}{l}.172 * * * \\
(1.363)\end{array}$ & $\begin{array}{l}.188^{* * *} \\
(1.694)\end{array}$ \\
\hline Just Friends & & & & & $\begin{array}{l}.151^{* * * *} \\
(1.344)\end{array}$ \\
\hline Divorced/Separated & & & & & $\begin{array}{l}.109 * * * \\
(3.070)\end{array}$ \\
\hline Romantic/not Married & & & & & $\begin{array}{c}.126^{*} \\
(1.617)\end{array}$ \\
\hline Father and Mother Married & & & & & $\begin{array}{l}.118^{*} \\
(1.749)\end{array}$ \\
\hline Constant(all $\mathrm{p}<.001$ ) & $\begin{array}{l}28.822 \\
(1.131)\end{array}$ & $\begin{array}{l}30.833 \\
(1.851)\end{array}$ & $\begin{array}{l}30.028 \\
(1.865)\end{array}$ & $\begin{array}{l}21.337 \\
(1.607)\end{array}$ & $\begin{array}{l}16.704 \\
(1.872)\end{array}$ \\
\hline $\begin{array}{l}\text { Adjusted } \mathrm{R}^{2} \\
\text { Adjusted } \mathrm{R}^{2} \text { Change }\end{array}$ & $\begin{array}{l}.02 * * * \\
.02\end{array}$ & $\begin{array}{l}.034^{* * * *} \\
.014\end{array}$ & $\begin{array}{l}.041 * * * \\
.007\end{array}$ & $\begin{array}{l}.315^{* * *} \\
.274 \\
\end{array}$ & $\begin{array}{l}328 * * * \\
.013 \\
\end{array}$ \\
\hline $\begin{array}{l}\mathrm{N}=3107 \\
\text { Beta is expressed as an unstan } \\
{ }_{* * *} \mathrm{p}<.001,{ }^{* *} \mathrm{p}<.01,{ }^{*} \mathrm{p}<.0\end{array}$ & ed coeffi & followedb & standard & nparenthe & heach cell. \\
\hline
\end{tabular}




\section{WORKS CITED}

Allen, William D. and Michael Connor. 1997. "An African American Perspective on Generative Fathering." In Generative Fathering: Beyond Deficit Perspective. Ed. Timothy Brubaker. Thousand Oaks, CA: Sage Publications.

Amato, Paul R. 1998. “More Than Money: Men's Contributions to their Children's Lives" In Men in Families. Ed. Alan Booth and Ann C. Crouter. Mahwah, New Jersey: Lawrence Erlbaum Associates.

Anderson, Elijah. 1989. "Sex Codes and Family Life Among Poor Inner City Youths." Annals of the American Academy of Political and Social Science 501:59-78.

Anderson, Elijah. 1998. Code of the Street: Decency, Violence and the Moral Life of the Inner City New York: W.W. Norton and Company.

Babbie, Earl. 2001. The Practice of Social Research (Ninth Edition). Belmont, CA: Wadsworth.

Babbie, Earl. 1990. Survey Research Methods (Second Edition). Belmont, CA: Wadsworth.

Barnet, Rosalind C. and Grace K. Baruch. 1987. "Determinants of Fathers' Participation in Family Work." Journal of Marriage and the Family 49(1):29-40.

Bartlett, M.S. 1954. "A Note on Multiplying Factors For Various Chi Square Approximations." Journal of the Royal Statistical Society 16(8):296-298.

Burton, Linda M. and Anastasia R. Snyder. 1998. "The Invisible Man Revisited: Comments on the Life Course, History, and Men's Roles in American Families." In Men in Families. Ed. Alan Booth and Ann C. Crouter. Mahwah, New Jersey: Lawrence Erlbaum Associates.

Cabrera, Natasha and V. Jeffrey Evans. 2000. "Wither Fathers in Welfare Reform." Poverty Research News 4(2).

Cabrera, Natasha J, Jacqueline D. Shannon, Cheri Vogel, Catherine Vogel, Catherine Tamis-LeMonda, Rebecca Ryan, Jeanne Brooks-Gunn, Helen Raikes, Rachel Cohen. 2004. "Low Income Fathers' Involvement in Their Toddlers' Lives: Biological Fathers from the Early Head Start Research Evaluation." Fathering Winter2004.

Carlson, Marcia, Sara McLanahan, Jeanne Brooks-Gunn. 2005. "Unmarried But Not Absent: Fathers' Involvement With Children After a Nonmarital Birth." Working Paper \#2005-07-FF. Center for Research on Child Wellbeing. Princeton University: Princeton, New Jersey. 
Carlson, Marcia and Sara McLanahan. 2002. "Involvement by Young Unmarried Fathers before and after Their Baby's Birth." The Prevention Researcher 11(4):14-17.

Cazenave Noel A. and George H. Leon. 1987. "Men's Work and Family Roles and Characteristics: Race, Gender, and Class." In Changing Men: New Directions in Research on Men and Masculinity. Ed. Michael Kimmel. Newbury Park, CA: Sage.

Coley, Rebekah Levine and P. Lindsay Chase-Lansdale. 2000. "Father's Involvement with Their Children Over Time." Poverty Research News 4(2). Joint Center for Poverty Research.

Coley, Rebekah Levine and P. Lindsay Chase-Lansdale. 1999. "Stability and Change in Paternal Involvement Among Urban African American Fathers." Journal of Family Psychology 13(3):1-20.

Coltrane, Scott. 2000. "Research on Household Labor: Modeling and Measuring the Social Embeddedness of Routine Family Work." Journal of Marriage and the Family 62:1208-1233.

Coltrane, Scott. 2001. "Stability and Change in Chicano Men's Family Lives." In Men's Lives (Fifth Edition). Ed. Michael Kimmel and Michael Messner. 451466. Allyn \& Bacon: Needham Heights, MA.

Coverman, Shelly. 1985. "Explaining Husbands' Participation in Domestic Labor." Sociological Quarterly 26:81-97.

Danziger, Sandra K. and Norma Radin. 1990. "Absent Does Not Equal Uninvolved." Journal of Marriage and Family 52:636-642.

Danziger, Sandra, Ariel Kalil, and Nathaniel Anderson. 2001. "Human Capital, Physical Health, and Metal Health of Welfare Recipients: Co-Occurrence and Correlates." Journal of Social Issues 56:635-654.

Edin, Kathryn, Laura Lein and Timothy Nelson. 1998. "Low-Income, Non-Residential Fathers: Off-Balance in a Competitive Economy; An Initial Analysis." HHS Fatherhood Initiative Report.

Edin, Kathryn, Laura Lein, Timothy Nelson, and Susan Clampet-Lundquist. 2000. "Talking with Low-Income Fathers." Poverty Research News 4(2). Joint Center for Poverty Research.

Edin, Kathryn and Timothy J. Nelson. 2001. "Working Steady: Race, Low-Wage Work, and Family Involvement Among Noncustodial Fathers in Philadelphia." Problem 
of the Century: Racial Stratification in the United States. New York: Russell Sage Foundation.

Edin, Kathryn, Laura Lein and Timothy Nelson. 1998. "Low-income, Non-residential Fathers: Off-balance in a Competitive Economy, an Initial Analysis."

Eggebeen, David and Chris Knoester. "Does Fatherhood Matter for Men?" Journal of Marriage and Family. 63:381-393.

Fathering Indicators Framework: a Tool for Quantitative and Qualitative Analysis. 2001. National Center on Fathers and Families. Philadelphia: Graduate School of Education, University of Pennsylvania.

Feagin, Joe R. and Kathryn D. McKinney. 2003. The Many Costs of Racism. Lanham, MD: Rowman and Littlefield Publishers, Inc.

Federal Interagency Forum on Child and Family Statistics. 1998. Nurturing Fatherhood: Improving Data and Research on Male Fertility, Family Formation and Fatherhood. Washington D.C. U.S. Government Printing Office.

Feige, Edgar L. 1989. ed. The Underground Economies: Tax Evasion and Informatin Distortion. Cambridge: Cambridge University press.

Feldman, Shirley, Sharon Nash and Barbara Aschenbrenner. 1983. "Antecedents of Fathering." Child Development 54:1628-1636.

Flouri, Eirini and Ann Buchanan. 2003. "What Predicts Fathers' involvement with Their Children? A Prospective Study of Intact Families." British Journal of Developmental Psychology 21:81-98.

Frey, Bruno S. and Werner Pommerehne. 1984. "The Hidden Economy: State and Prospect for Measurement." Review of Income Wealth 30(1):1-23.

Furstenberg, Frank F., Jr. 1995. "Fathering in the Inner City: Paternal Participation and Public Policy." Fatherhood: Contemporary Theory, Research, and Social Policy, ed. William Marsiglio. Thousand Oaks, CA: Sage Publications.

Furstenberg, Frank F. 1988. "Good Dads—Bad Dads: Two Faces of Fatherhood.” In The Changing American Family and Public Policy. ed. A.J. Cherlin. Washington D.C.: Urban Institute.

Furstenberg, Frank F., James L. Peterson, Christine Winquist Nord, and Nicholas Zinn. 1983. "Parenting Apart: Patterns of Childrearing After Marital Disruption." Journal of Marriage and the Family 47:893-904. 
Grossman, Frances, William Pollack, and Ellen Golding. 1988. "Fathers and Children: Predicting the Quality and Quantity of Fathering." Developmental Psychology 24:82-91.

Hawkins, Alan J. et al. 1993. "Rethinking Fathers' Involvement in Child Care: a Developmental Perspective.” Journal of Family Issues 14(4)531-549.

Heath, Daniel. 1978. "What Meaning and What Effects Does Fatherhood Have on the Maturing of Professional Men.” Merrill-Palmer Quarterly 24:265-278.

Hill, Robert Bernard and Robert B. Hill. 1999. The Strengths of African American Families: Twenty-Five Years Later. Landham, MD: University Press of America.

Introduction to the Fragile Families Public Use Baseline Data. 2003. Princeton, NJ: Princeton University.

Introduction to the Fragile Families One-Year Public Use Data. 2003. Princeton, NJ: Princeton University.

Ishii-Kuntz, Masako. 1994. "Paternal Involvement and Perception Toward Fathers' Roles.” Journal of Family Issues 15(1):30-48.

Jencks, Christopher. 1992. Rethinking Social Policy: Race, Poverty, and the Underclass. New York: HarperCollins Publishers.

Johnson, Waldo E. 2000. "The Determinants of Paternal Involvement Among Unwed Fathers." Working Paper \#00-19-FF. Center for Research on Child Wellbeing. Princeton University: Princeton, New Jersey.

Johnson, Waldo E. 2000a. "Paternal Involvement among Unwed Fathers." Poverty Research News 4(2). March/April. Joint Center for Poverty Research.

Kaiser, Henry. 1974. “An Index of Factorial Simplicity.” Psychometrika 39:31-36.

Kaiser, Henry. 1970. "A Second Generation Little Jiffy.” Psychometrika 35:401-415.

Kalil, Ariel. 2003. "Fathers Perceptions of Paternal Roles: Variations by Marital Status and Living Arrangement." Working Paper \#03-12-FF. Center for Research on Child Wellbeing. Princeton University: Princeton, New Jersey.

Katz, Michael B. 1990. The Undeserving Poor: From War on Poverty to War on Welfare. New York: Pantheon Books.

Kenney, Catherine. 2004. "Cohabiting Couple, Filing Jointly? Resource Pooling and U.S. Poverty Policies. Family Relations 53(2):237-248. 
Kohler, Julia K., Elaine A. Anderson, Linda Oravecz, and Bonnie Braun. 2004. "Relationship Constellations and Dynamics of Rural Mothers." Affilia 19(2):160173.

Lamb, Michael E. 1987. "Introduction: the Emergent Father." The Father's Role: a Cross-cultural Perspective. Hillsdale, NJ: Lawrence Erlbaum.

Lamb, Michael. 1998. "Fatherhood Then and Now." In Men in Families. In Men in Families. Ed. Alan Booth and Ann C. Crouter. Mahwah, New Jersey: Lawrence Erlbaum Associates.

Latimer, Melissa. 2004. "Between a Rock and a Hard Place-The Socioeconomic Status of Former TANF Recipients in West Virginia.” Sociological Spectrum 24:1.

Lemieux, Thomas, Bernard Fortin, and Pierre Frechette. 1994. "The Effect of Taxes on the Labor Supply in the Underground Economy." American Economic Review 84(1):231-254.

Lerman, Robert I. 1993. "Who Young Unwed Fathers Are." Young Unwed Fathers: Changing Roles and Emerging Policies. Philadelphia: Temple University Press.

Levitt, Steven D. and Sudhir Alladi Venkatesh. 1998. "An Economic Analysis of a Drug-Selling Gang's Finances." National Bureau of Economic Research Working Paper No. 6592. National Bureau of Economic Research: Cambridge, MA.

Levy, Frank. 1980. “Changes in Employment Prospects for Black Males.” Brooking Papers on Economic Activity 2:513-538.

Levy-Schiff, Rachael and Ruth Israelashvili. 1988. "Antecedents of Fathering: Some Further Exploration.” Developmental Psychology 24:434-440.

Liebow, Elliot. 1967. Tally's Corner: a Study of Negro Streetcorner Men. Boston: Little, Brown and Company.

Lubell, Herald. 1991. The Informal Sector in the 1980s and 1990. Paris, OECD.

Mandhubuti, Haki. 1990. Black Men: Obsolete, Single, Dangerous. Chicago: Third World Press.

Manning, Wendy and Daniel Lichter. 1996. "Parental Cohabitation and Children's Economic Well-being. Journal of Marriage and the Family 58:998-1010.

Marsiglio, William 1991. "Paternal Engagement Activities with Minor Children." Journal of Marriage and Family 53(4):973-986. 
Marsiglio, William. 1993. "Contemporary Scholarship on Fatherhood: Culture, Identity, and Conduct.” Journal of Family Issues 14(4):484-509.

Marsiglio, William. 1995. Fatherhood: Contemporary Theory, Research, and Social Policy. Thousand Oaks, CA: Sage Publications.

Massey, Douglas S. and Nancy A. Denton. 1993. American Apartheid: Segregation and the Making of the Underclass. Cambridge, MA: Harvard University Press.

McAdoo, John Lewis. (1981). Black Father and Child Interactions. In BlackMen ed. E Gary. Beverly Hills, CA: Sage.

McHale, Susan and Ted Huston. 1984. "Men and Women as Parents: Sex Role Orientations, Employment, and Parental Roles with Infants.” Child Development $55: 1349-1361$.

McLoyd, Vonnie C., Ana Mari Cauce, David Takeuchi, and Leon Wilson. 2000. "Marital Processes and Parental Socialization in Families of Color: a Decade Review of Research." Journal of Marriage and the Family 62(4):1070-1093.

Merton, Robert K. 1938. "Social Structure and Anomie." American Sociological Review 3(5):672-682).

McLanahan, Sara L. 2001. "Life Without Father: What Happens to the Children?" Working Paper \#01-21. Center for Research on Child Wellbeing. Princeton University: Princeton, New Jersey.

National Center on Fathers and Families (NCOFF). 1999. Fathering Indicators Framework: A Tool for Quantitative and Qualitative Analysis. University of Pennsylvania, Philadelphia.

Newman, Katherine. 1988. Falling from Grace: Downward Mobility in an Age of Affluence. Berkeley, CA: University of California Press.

NICHD. 2000. "Factors Associated with Fathers' Caregiving Activities and Sensitivity with Young Children.” Journal of Family Psychology 14:200-219.

Nock, Steven L. 1998. In Men in Families. Ed. Alan Booth and Ann C. Crouter. Mahwah, New Jersey: Lawrence Erlbaum Associates.

Nock, Steven L. and Paul Kingston. 1988. "Time with Children: The Impact of Couples Work-time Commitments." Social Forces 67:59-85. 
Norland, Christina. 2001. "Unwed Fathers, the Underground Economy, and Child Support Policy.” Fragile Families Research Brief. Princeton University: Princeton, New Jersey.

O'Campo, P. and L. Rojas-Smith. 1998. "Welfare Reform and Women's Health: Review of the Literature and Implications for State Policy." Journal of Public Health Policy 19:420-446.

Pallant, Julie. 2001. SPSS Survival Manual. New York: Open University Press.

Pattillo-McCoy, Mary. 2000. Black Picket Fences: Privilege and Peril Among the Black Middle Class. Chicago: The University of Chicago Press.

Pleck, Joseph H. 1987. “American Fathering in Historical Perspective.” Changing Men: New Directions in Research on Men and Masculinity. ed. Michael Kimmel. Newbury Park, CA: Sage.

Price-Bonham, Sharon and Patsy Skeen. 1979. "A Comparison of Black and White Fathers with Implications for Parent Education." The Family Coordinator 28: 5359.

Reichman, Nancy, Julien Teitler, Irwin Garfinkel, and Sara McLanahan. 2001. "The Fragile Families and Child Wellbeing Study: Sample and Design." Children and Youth Services Review 23(4/5):277-452.

Reichman, Nancy, Julien Teitler, Irwin Garfinkel, and Sara McLanahan. 2002. "The Role of Welfare in New Parents' Lives." Working Paper \#02-11-FF. Center for Research on Child Wellbeing: Princeton University: Princeton, New Jersey.

Rich, Lauren. 2003. "Regular and Irregular Earnings of Fathers with Nonmarital Births: Implications for Child Support Practices?” Working Paper \#99-10-FF. Center for Research on Child Wellbeing: Princeton University, Princeton, New Jersey.

Rich, Lauren. 1999. "Regular and Irregular Earnings of Unwed Fathers: Implications for Child Support Practices." Working Paper \#99-10-FF. Center for Research on Child Wellbeing: Princeton, University, Princeton: New Jersey.

Rich, Lauren and Sun-Bin Kim. 2001. "Taxes and Unmarried Fathers' Participation in the Underground Economy." Working Paper \#01-19-FF. Center For Research on Child Wellbeing: Princeton University, Princeton, New Jersey.

Rubin, Lillian. 1994. Families on the Fault Line: American's Working Class Speaks about the Family, the Economy, Race, and Ethnicity. New York: HarperCollins Publishers. 
Schneider, Friedrich and Dominik H. Enste. 2000. "Shadow Economies: Size, Causes, and Consequences." Journal of Economic Literature 38(1):77-114.

Schlosser, Eric. 2003. Reefer Madness: Sex, Drugs, and Cheap Labor in the American Black Market. New York: Houghton Mifflin Company.

Seltzer, Judith A. 1991. "Relationships Between Fathers and Children Who Live Apart: the Father's Role After Separation." Journal of Marriage and Family 53:79-101.

Seltzer, Judith A. and Suzanne M. Bianchi. 1988. "Children's Contact with Absent Parents." Journal of Marriage and the Family 50:663-677.

Shelton, B.A. and John, D. 1993. "Ethnicity, Race, and Difference: a Comparison of White, Black, and Hispanic Men's Household Labor Time." Pp. 131-150 in Men, Work, and Family. Ed. J.C. Hood. Newbury Park, CA: Sage.

Stier, Haya and Marta Tienda. 1993. "Are Men Becoming Marginal to the Family?: Insight From Chicago's Inner City." Men, Work, and Family. Newbury Park, CA: Sage Publications, Inc.

Sullivan, Mercer L. 1993. "Young Fathers and Parenting in Two Inner-City Neighborhoods." Young Unwed Fathers: Changing Roles and Emerging Policies. Temple University Press: Philadelphia.

Sullivan, Mercer. 1989. "Absent Fathers in the Inner City." Annals of the American Academy of Political and Social Science 501:48-58.

Tamis-LeMonda, Catherine. 2004. "Conceptualizing Fathers' Roles: Playmates and More." Human Development 47:220-227.

Venkatesh, Sudhir A. 2000. American Project: The Rise and Fall of a Modern Ghetto. Cambridge, MA: Harvard University Press.

Volling, Brenda and Jay Belsky. 1988. The Determinants of Father Involvement in Dualearner and Single-earner Families. National Council on Family Relations.

Philadelphia.

Volling, Brenda and Jay Belsky. 1991. "Multiple Determinants of Father Involvement During Infancy in Dual-earner and Single-earner Families." Journal of Marriage and the Family 53 (2):461-474.

Waller, Maureen and Amanda Bailey. 2002. "How Do Fathers' Negative Behaviors Shape Relationships with Their Children?" Working Paper \#02-18-FF. Center for Research on Child Wellbeing: Princeton University, Princeton, New Jersey. 
Wilson, William Julius. 1980. The Declining Significance of Race. Chicago: The University of Chicago Press.

Wilson, William Julius. 1996. When Work Disappears: The World of the New Urban Poor. New York: Alfred A. Knopf

Wilson, William Julius and Kathryn M. Neckerman. 1986. "Poverty and Family Structure: The Widening Gap between Evidence and Public Policy Issues." Fighting Poverty. Ed. Sheldon Danziger and Daniel Weinberg. Cambridge: Harvard University Press. 


\footnotetext{
${ }^{1}$ Page 8 of this thesis contains an explanation of the concepts of availability, engagement, and responsibility from the existing literature.

${ }^{2}$ The Fathering Indicators Framework theoretically includes this activity in the "responsibility" category of father involvement rather than engagement.

${ }^{1}$ I regressed total hours worked in all economies in a separate regression model not included here. I constructed this variable by combining hours spent hustling, hours worked off-the-books, and the survey item: "In the last 12 months, how many weeks did you work (at all of your regular jobs/at your job)?" I also squared each item to examine curvilinear relationships. I also squared the following variables: total hours worked, regular hours worked, hustle, and off-the-books. Since the results of this analysis are outside the scope of this thesis, they are available upon request.

${ }^{3}$ Chapter 2 describes how these idiosyncratic variables affect father involvement.

${ }^{4}$ I ran a second regression analysis to examine the effects hours ${ }^{2}$ in each employment sector on father involvement. This table is available upon request.

${ }^{5}$ A score of 49 would indicate that fathers completed all seven activities in the scale every day of the week

${ }^{6}$ In $1999,18 \%$ of all males, ages 15 and over had attended some college, and $23 \%$ of the same population had at least a Bachelor's degree or higher according to the U.S. Census Bureau.

${ }^{7}$ I tested for mediator effects by deriving a two-step hierarchical regression model, using the status of African American as the independent variable, hours spent hustling as the mediator, and father involvement as the dependent variable. I found that hours spent hustling and hours spent doing regular work partially mediates the association between being African American and father involvement. Hours spent hustling did not mediate the association between being Latino and father involvement.

${ }^{8}$ I derived two, two-step hierarchical regression models and found that being Latino significantly predicted father involvement when accompanied by educational attainment controls. In the first equation, being Latino positively predicted father involvement when combined with graduating from college. In the second instance, being Latino positively predicted father involvement when combined with not graduating from high school. In this second case, not graduating from high school suppresses the variance in being Latino that is not accounted for in father involvement.

${ }^{8}$ I tested for mediator effects by deriving a two-step hierarchical regression model, using the status of African American as the independent variable, cohabiting all the time as the mediator, and father involvement as the dependent variable. I found that cohabiting all the time partially mediates the association between being African American and father involvement.

${ }^{9}$ The two-step hierarchical regression model I derived by using the status of regular hours worked as the independent variable, cohabiting all the time as the mediator, and father involvement as the dependent variable evidences that cohabiting all the time partially mediates the association between being African American and father involvement.

${ }^{10}$ In a separate analysis, I derived a new model that included a variable measuring hours worked in all labor market sectors. This new variable, as well as all other key independent variables from Model 1 , lost significance as predictors of father involvement after I controlled for cohabitation in Model 4. The results of this OLS regression analysis are available upon request.

I also squared hours worked in each of the four variables to test for curvilinear relationships. Hustles remained statistically significant as a negative predictor of father involvement $(\mathrm{b}=-.857, \mathrm{p} \leq .001)$, unless done in large amounts. Hustles square was statistically significant a as a very weak but positive predictor of father involvement $(\mathrm{b}=.015, \mathrm{p} \leq .001)$. Finally, regular work became statistically significant as a positive predictor of father involvement in this run $(b=.143, p \leq .01)$. These results are available upon request.

${ }^{11} \mathrm{I}$ am hesitant to make general conclusions about divorced fathers in fragile families because the number of marriages ending in divorce in this sample is only $1 \%$ of the sample. Also, none of these fathers generated income through hustling, which is one of my key independent variables. Future studies should examine a larger sample of divorced fathers working in all sectors of the labor market to draw accurate conclusions

${ }^{12}$ In a separate linear regression, I found that regular hours worked significantly and positively predicted cohabitation $(\mathrm{b}=.004, \mathrm{p}<.001)$ and marriage $(\mathrm{b}=.004, \mathrm{p}<.001)$.
} 